\title{
Antitumor effect of forbesione isolated from Garcinia hanburyi on cholangiocarcinoma in vitro and in vivo
}

\author{
PARICHART BOUEROY ${ }^{1-3}$, CHARIYA HAHNVAJANAWONG $^{1-3}$, \\ THIDARUT BOONMARS ${ }^{3,4}$, SUNITTA SAENSA-ARD ${ }^{1-3}$, NATTHINEE ANANTACHOKE ${ }^{2,5}$, \\ KULTHIDA VAETEEWOOTTACHARN ${ }^{3,6}$ and VICHAI REUTRAKUL ${ }^{2,7}$ \\ ${ }^{1}$ Department of Microbiology; ${ }^{2}$ Center of Excellence for Innovation in Chemistry; \\ ${ }^{3}$ Liver Fluke and Cholangiocarcinoma Research Center; ${ }^{4}$ Department of Parasitology, Faculty of Medicine, \\ Khon Kaen University, Khon Kaen 40002; ${ }^{5}$ Department of Pharmacognosy, Faculty of Pharmacy, Mahidol University, \\ Bangkok 10400; ${ }^{6}$ Department of Biochemistry, Faculty of Medicine, Khon Kaen University, Khon Kaen 40002; \\ ${ }^{7}$ Department of Chemistry, Faculty of Science, Mahidol University, Bangkok 10400, Thailand
}

Received May 6, 2015; Accepted September 22, 2016

DOI: $10.3892 / \mathrm{ol} .2016 .5284$

\begin{abstract}
Cholangiocarcinoma (CCA) is a malignancy with no effective therapy and poor prognosis. Forbesione, a caged xanthone isolated from Garcinia hanburyi, has been reported to inhibit proliferation and to induce apoptosis in human CCA cell lines. The present study aimed to further explore the potential anticancer properties of forbesione by testing its effects against the hamster CCA cell line Ham-1 in vitro and in vivo. It was observed that forbesione inhibited the growth of Ham-1 cells in vitro and suppressed Ham-1 growth as allograft in hamsters by inducing cell cycle arrest at the $S$ phase. This was mediated by decreasing the protein expression of cyclin E, cyclin A and cyclin-dependent kinase 2. In addition, increased expression of p21 and p27 was detected, which could possibly explain the reduced expression of proliferating cell nuclear antigen and of the bile duct cell marker cytokeratin 19 observed in forbesione-treated Ham-1 cells in vitro and in tumor tissues of forbesione-treated hamsters. Furthermore, forbesione induced apoptosis through multiple pathways. The death receptor pathway was activated by increased expression of Fas, Fas-associated death domain and activated caspase-3, along with decreased expression of procaspase- 8 and procaspase- 3 . The mitochondrial pathway was driven by increased expression of B-cell lymphoma (Bcl)-2-like protein 4, activated caspase-9 and inhibitor of $\kappa \mathrm{B}-\alpha$, along with decreased expression of $\mathrm{Bcl}-2$, survivin, procaspase- 9 and nuclear factor $-\kappa \mathrm{B} / \mathrm{p} 65$. The
\end{abstract}

Correspondence to: Dr Chariya Hahnvajanawong, Department of Microbiology, Faculty of Medicine, Khon Kaen University, 123 Pre-clinical building Mittraphap Road, Muang, Khon Kaen 40002, Thailand

E-mail: hchari@kku.ac.th

Key words: cholangiocarcinoma, forbesione, apoptosis, cell cycle arrest endoplasmic reticulum pathway was stimulated by increased expression of activated caspase-12 and decreased expression of procaspase-12. No side effects or toxicity were observed in forbesione-treated hamsters. Thus, forbesione is a potential drug candidate for cancer therapy that deserves further investigation.

\section{Introduction}

Cholangiocarcinoma (CCA), the malignant tumor of biliary epithelial cells, is the cancer of highest incidence in northeastern Thailand (1), and has increasing incidence and mortality worldwide $(2,3)$. More than $70 \%$ of CCA patients have an advanced stage of the disease at the time of diagnosis, which makes curative surgical resection unfeasible (4). In these advanced CCA patients, chemotherapy is the usual treatment option (5). The systemic chemotherapy choices currently offered are 5-fluorouracil (5-FU), carboplatin plus 5-FU, gemcitabine and paclitaxel, which have failed to improve survival, and response rates are only $20 \%$ (4). New therapeutic agents for CCA are urgently required.

In the past few decades, natural bioactive substances derived from plants have been considered as important antitumor drug sources (6). Forbesione is a caged xanthone isolated from the resin and fruits of Garcinia hanburyi Hook. f. (family Guttiferae), which have been used in Thai traditional medicine $(6,7)$. Gambogic acid, forbesione, isomorellin and isomorellinol, the caged xanthones isolated from G. hanburyi, are reported to exhibit antitumor activities (8) and cytotoxic effects in several cancer cell lines (8-10). Gambogic acid is the most intensively studied caged xanthone, and exhibits potent antitumor activity in vitro and in vivo (11-13) through several mechanisms, including inhibition of topoisomerase II alpha activity (14), downregulation of telomerase (15), induction of cell cycle arrest (16) and induction of apoptosis (17). Due to its low toxicity against normal tissues $(18,19)$, gambogic acid is now approved for a phase II clinical trial in China (20).

The results from our previous in vitro studies demonstrated that gambogic acid, forbesione, isomorellin and isomorellinol 
selectively inhibited the proliferation of the human CCA cell lines KKU-100 and KKU-M156 by inducing apoptosis through the mitochondrial pathway (6), and by inducing $G_{0} / G_{1}$-phase cell cycle arrest through p53 and the nuclear factor $(\mathrm{NF})-\kappa \mathrm{B}$ signaling pathway (21). Our previous studies demonstrated that combinations of isomorellin/doxorubicin and forbesione/doxorubicin exhibited significant synergy for inhibition of cell growth and induction of apoptosis in KKU-M156 and KKU-100 cells, respectively, through suppression of multidrug resistance-associated protein $1, \mathrm{NF}-\kappa \mathrm{B}$ activation, enhanced expression of B-cell lymphoma (Bcl)-2-like protein $4(\mathrm{Bax}) / \mathrm{Bcl}-2$, activation of caspase- 9 and caspase-3, and suppression of the expression of survivin, procaspase- 9 and procaspase-3 (22).

To date, the effects of caged xanthones on CCA in vivo have not yet been reported. In the present study, the growth-inhibitory effect of forbesione on Ham-1 CCA cells was investigated in vitro and in vivo when grown as allografts. It was observed that forbesione inhibits Ham-1 cell growth in vitro and suppresses allograft tumor growth. Furthermore, our study suggested that the possible mechanisms are the induction of cell cycle arrest at the $\mathrm{S}$ phase by altering the expression of cell cycle-regulated proteins [including cyclin E, cyclin A, cyclin-dependent kinase 2 (Cdk2), p21, p27 and proliferating cell nuclear antigen (PCNA)] and by inducing multiple pathways of apoptosis [including the death receptor pathway, the mitochondrial pathway and the endoplasmic reticulum (ER) pathway]. This which was achieved by altering the expression of genes and proteins related to apoptosis regulation, including Fas, Fas-associated death domain (FADD), procaspase-8, activated caspase-3, Bcl-2, Bax, survivin, activated caspase- 9 , activated caspase- $12, \mathrm{NF}-\kappa \mathrm{B} / \mathrm{p} 65$ and inhibitor of $\kappa \mathrm{B}-\alpha(\mathrm{I} \kappa \mathrm{B}-\alpha)$.

\section{Materials and methods}

Materials. Forbesione (Fig. 1) was extracted from G. hanburyi Hook. f. (family Guttiferae) using bioassay-directed fractionation (10). Forbesione was dissolved in dimethyl sulfoxide (DMSO) to create a stock solution of $1.8 \mathrm{mM}$ that was stored at $-20^{\circ} \mathrm{C}$. Annexin-V-FLOUS Staining kit was purchased from Roche Applied Science (Penzberg, Germany); ethidium bromide/acridine orange $(\mathrm{EB} / \mathrm{AO})$ mixture was purchased from Sigma-Aldrich (Merck Millipore, Darmstadt, Germany); and chemiluminescence reagent, RNasin Ribonuclease Inhibitor, DNase I, oligo(dT), Moloney-murine leukemia virus (M-MLV) polymerase and TrueStart Hot Start Taq DNA polymerase were purchased from Pierce (Thermo Fisher Scientific, Inc., Waltham, MA, USA). TRIzol ${ }^{\circledR}$ reagent was purchased from Invitrogen (Thermo Fisher Scientific, Inc.). Primary antibodies against Bax, Bcl-2, survivin, caspase-9, procaspase-3, Fas, FADD, procaspase-8, cyclin E, cyclin A, Cdk2, p21, p27, I $\kappa \mathrm{B}-\alpha$ and $\mathrm{NF}-\kappa \mathrm{B} / \mathrm{p} 65$, as well as secondary antibodies, were purchased from Santa Cruz Biotechnology, Inc. (Dallas, TX, USA). Activated caspase-3 and $\beta$-actin were purchased from Sigma-Aldrich (Merck Millipore), while caspase-12 was purchased from Chemicon International, Inc. (Temecula, CA, USA). Anti-cytokeratin 19 (CK19) antibody was purchased from Abcam (Cambridge, UK), while anti-PCNA antibody was purchased from Novocastra Laboratories Ltd. (Newcastle upon Tyne, UK). Anti-rabbit and anti-mouse horseradish peroxidase-streptavidin conjugates were purchased from Zymed Laboratories (Thermo Fisher Scientific, Inc.). The primary and secondary antibodies used in the present study are listed and characterized in Tables I and II.

Cell culture. The cell line Ham-1 (23), derived from the CCA tissue of Opisthorchis viverrini-infected and N-nitrosodimethylamine-treated Syrian hamsters, which was established at the Department of Biochemistry, Faculty of Medicine, Khon Kaen University (Khon Kaen, Thailand), was used in the present study. Ham-1 cells were cultured in Dulbecco's modified Eagle medium (DMEM; Gibco; Thermo Fisher Scientific, Inc.) supplemented with $10 \%$ heat-inactivated fetal bovine serum (FBS; Gibco; Thermo Fisher Scientific, Inc.), $100 \mathrm{U} / \mathrm{ml}$ penicillin and $100 \mu \mathrm{g} / \mathrm{ml}$ streptomycin, and maintained at $37^{\circ} \mathrm{C}$ in a $5 \% \mathrm{CO}_{2}$ humidified incubator.

Sulforhodamine B (SRB) assay for cell number determination. Ham-1 cells were seeded into 96-well plates (Costar; Corning Incorporated, Corning, NY, USA) at a density of $1 \times 10^{4}$ cells/well. The cytotoxicity of forbesione was determined using the SRB assay as previously described (24).

Cell cycle analysis. Ham-1 cells $\left(3 \times 10^{5}\right.$ cells/well) seeded in 6-well plates were treated with various forbesione concentrations for $24 \mathrm{~h}$. Cells were harvested by trypsinization, washed twice with cold PBS, fixed in $70 \%$ ethanol at $4^{\circ} \mathrm{C}$ overnight, centrifuged at $1,000 \times \mathrm{g}$ for $10 \mathrm{~min}$ at $4^{\circ} \mathrm{C}$, incubated for $45 \mathrm{~min}$ with RNase A (final concentration, $2 \mu \mathrm{g} / \mathrm{ml}$ ) and then stained with propidium iodide (PI) (final concentration, $2.4 \mu \mathrm{g} / \mathrm{ml}$ ) for $1 \mathrm{~h}$ on ice in the dark. The DNA content and cell cycle distribution of the cells were analyzed by FACSCalibur (BD Biosciences, Franklin Lakes, NJ, USA).

Morphological characterization of cell death. Ham-1 cells were treated with varying concentrations of forbesione for $24 \mathrm{~h}$ and then stained with $14 \mu \mathrm{l}$ of $100 \mu \mathrm{g} / \mathrm{ml}$ EB/AO mixture. Apoptotic cells with condensed or fragmented chromatin were determined with an Eclipse Ni-U microscope (Nikon Corporation, Tokyo, Japan).

Assessment of apoptosis using flow cytometry. Ham-1 cells were exposed to different concentrations of forbesione for 6, 24 or 48 h. Floating and adherent cells were harvested by trypsinization, washed with cold PBS and centrifuged at $1,000 \times \mathrm{g}$ for $10 \mathrm{~min}$ at $4^{\circ} \mathrm{C}$. Pelleted cells were resuspended in $400 \mu \mathrm{l}$ of PBS and then stained with $100 \mu \mathrm{l}$ of incubation buffer containing $2 \mu \mathrm{l}$ of annexin V-fluorescein isothiocyanate (FITC) and $2 \mu \mathrm{l}$ of PI for 10-15 min at room temperature in the dark, prior to analysis by flow cytometry (BD Biosciences).

Western blot analysis. Ham-1 cells were seeded in 10-cm-diameter dishes (Costar; Corning Incorporated) at a density of $1 \times 10^{6}$ cells/dish and incubated with various concentration of forbesione for $24 \mathrm{~h}$. Harvested cells were washed twice with cold PBS and lysed with ice-cold radioimmunoprecipitation assay buffer [50 mM Tris- $\mathrm{HCl}$ (pH 7.5), $150 \mathrm{mM} \mathrm{NaCl}, 0.5 \%$ Nonidet P-40, 1 mM EDTA, 1 mM dithiothreitol, 0.5\% deoxycholate and $0.1 \%$ SDS] with protease inhibitor cocktail (Pierce; Thermo Fisher Scientific, Inc.) and phosphatase inhibitor 


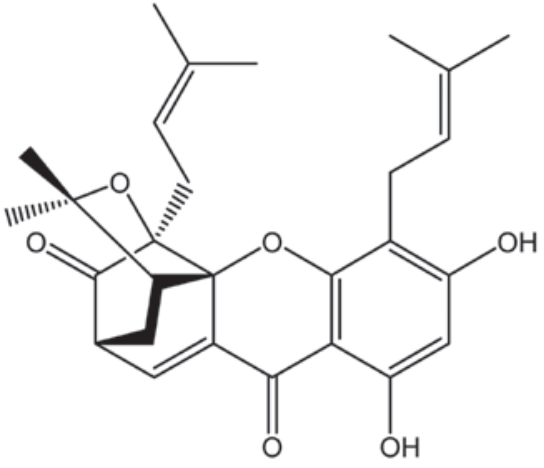

Forbesione

Figure 1. Chemical structure of forbesione.

cocktail (Pierce; Thermo Fisher Scientific, Inc.). The cell lysates were homogenized and clarified by centrifugation at 15,000 x $g$ for $30 \mathrm{~min}$ at $4^{\circ} \mathrm{C}$. The protein concentration of the total cell lysate was determined by the method of Bradford (25). Cell lysates were fractionated by $12 \%$ SDS-PAGE and transferred to nitrocellulose membranes. Membranes were blocked with 5\% nonfat milk in $0.1 \%$ Tween 20 in PBS at $37^{\circ} \mathrm{C}$ for $1 \mathrm{~h}$, followed by incubation with the corresponding primary $\beta$-actin $(1: 3,000)$, Bcl-2 (1:200), Bax (1:200), survivin (1:400), caspase-9 (1:200), procaspase-3 (1:400), activated caspase-3 (1:400), Fas (1:400), FADD (1:400), procaspase-8 (1:400), cyclin E (1:400), cyclin A (1:400), Cdk2 (1:200), p21 (1:400), p27 (1:200), IкB- $\alpha$ (1:500), NF- $\kappa$ B/p65 (1:500), caspase-12 (1:200), CK19 (1:500) and PCNA (1:500) antibodies at $4^{\circ} \mathrm{C}$ overnight. Next, membranes were washed with $0.1 \%$ Tween 20 in PBS and incubated with the appropriate secondary antibodies (anti-mouse or anti-rabbit; 1:10,000). The bound secondary antibody-POD conjugates were visualized using an enhanced chemiluminescence reagent (Pierce; Thermo Fisher Scientific, Inc.), quantified by densitometry (ImageQuant LAS 4000; GE Healthcare Life Sciences, Chalfont, UK) and analyzed using the program Scion Image (Version 4.0.2; Scion Corporation, Frederick, MD, USA). Data for each protein expressed were normalized to $\beta$-actin expression.

Experimental allografts of Ham-1 in hamsters. A total of 12 male Syrian hamsters aged 6-8 weeks (Animal Unit, Faculty of Medicine, Khon Kaen University, Khon Kaen, Thailand) were maintained at $22^{\circ} \mathrm{C}$ and exposed to $12 \mathrm{~h}$ light/dark cycles with free access to food and water. The hamsters were injected intradermally with $2.5 \times 10^{5} \mathrm{Ham}-1$ cells in $50 \mu \mathrm{l}$ of $1 \%$ FBS in DMEM into the flank. After the tumors had become established ( $\sim 3$ days), those tumors whose volume had reached $10-20 \mathrm{~mm}^{3}$ were selected. Syrian hamsters were randomly allocated into two groups ( $n=6 /$ group): i) Negative control group (1\% DMSO, oral every day); and ii) forbesione ( $50 \mathrm{mg} / \mathrm{kg}$, oral every day) for 1 month. The day of first treatment was set as day 1 . The size of the tumors was assessed every other day, and tumor volume was determined using the following equation: Tumor volume $\left(\mathrm{mm}^{3}\right)=\left(\mathrm{a} \mathrm{x} \mathrm{b}^{2}\right) / 2$ (where $\mathrm{a}$ and $\mathrm{b}$ refer to the longest and shortest dimension in $\mathrm{mm}$, respectively) (12). The animals were weighed, and food and water intake was measured daily. The physical activity and mortality of the animals was monitored daily during the experimental period to assess the toxicity of the treatments. All the protocols were approved by the animal ethics committee of Khon Kaen University (Khon Kaen, Thailan; approval no. AEKKU 2/2556).

Reverse transcription-quantitative polymerase chain reaction $(R T-q P C R)$. Total RNA was isolated from tumor tissues with TRIzol $^{\circledR}$ solution (Invitrogen; Thermo Fisher Scientific, Inc.) according to the manufacturer's protocol. Complementary DNA (cDNA) was synthesized from $3 \mu \mathrm{g}$ of total RNA using $0.5 \mu \mathrm{g} / \mu \mathrm{l}$ of oligo(dT) 15 primers, $20 \mathrm{U}$ of RNase inhibitor, $20 \mathrm{U}$ of M-MLV (Pierce; Thermo Fisher Scientific, Inc.), $10 \mathrm{mM}$ deoxynucleotides (dNTPs) and M-MLV reverse transcriptase $5 \mathrm{X}$ reaction buffer. RT-qPCR was performed using the $\mathrm{SYBR}^{\circledR}$ Green method on a CFX96 Touch $^{\mathrm{TM}}$ Real-Time PCR Detection System (Bio-Rad Laboratories, Inc., Hercules, CA, USA) to analyze the relative abundance of each individual messenger RNA (mRNA) relative to that of GAPDH, which was used as an endogenous control. The reaction mixture contained $3 \mu \mathrm{l}$ of 1:10 diluted single-strand cDNA, $2 \mu \mathrm{l}$ of 10X HotStar Taq polymerase buffer, $1 \mu \mathrm{l}$ of each $5 \mathrm{mM}$ dNTP, $2.4 \mu 1$ of $25 \mathrm{mM}$ $\mathrm{MgCl}_{2}, 1 \mu \mathrm{l}$ of $5 \mu \mathrm{M}$ primer pairs, $0.2 \mu \mathrm{l}$ of HotStar Taq DNA polymerase (Pierce; Thermo Fisher Scientific, Inc.) and $7.4 \mu \mathrm{l}$ of distilled water to a final volume of $20 \mu \mathrm{l}$. PCR cycling conditions were as follows: Initital denaturation at $95^{\circ} \mathrm{C}$ for $10 \mathrm{sec}$ followed by $35-50$ cycles of $95^{\circ} \mathrm{C}$ for $15 \mathrm{sec}, 52-62 \mathrm{C}$ for $60 \mathrm{sec}$ and $72^{\circ} \mathrm{C}$ for $1 \mathrm{~min}$, with a final extension step at $72^{\circ} \mathrm{C}$ for $10 \mathrm{~min}$. The PCR primers for GAPDH (26), CK19, apoptotic protease activating factor (Apaf)-1 (27), Bax (26), caspase-9 and caspase-3 (Integrated DNA Technologies, Coralville, IA, USA) are summarized in Table III. Relative expression of CK19, Apaf-1, Bax, caspase- 9 and caspase-3 mRNA was calculated using the comparative $\Delta \Delta \mathrm{Cq}$ method as previously described (28). All the values were reported as fold-change over background levels detected in the untreated control as a calibrator.

Immunohistochemical (IHC) staining for PCNA, CK19, cyclin A, Bcl-2, Bax, caspase-9 and caspase-3. Formalin-fixed, paraffin-embedded blocks of allograft tissues were prepared, and sections $(4-\mu \mathrm{m})$ were deparaffinized in xylene and rehydrated through graded alcohol series to water. Sections were rinsed for 5 min in distilled water, and antigen retrieval was performed by autoclaving the sections in $50 \mathrm{mM}$ citrate buffer ( $\mathrm{pH} \mathrm{6.0)}$ for $5 \mathrm{~min}$ at $121^{\circ} \mathrm{C}$ and treating them for $30 \mathrm{~min}$ in methanol containing $3 \% \mathrm{H}_{2} \mathrm{O}_{2}$ to block any endogenous peroxidase activity. Upon blocking with 5\% skim milk in PBS, the sections were incubated with the primary monoclonal antibodies against CK19 (a marker of bile duct epithelium), PCNA (a proliferation marker), cyclin A (an S-phase cell cycle-regulated protein), or Bcl-2, Bax, caspase-9 or caspase-3 (apoptosis-related proteins) at $37^{\circ} \mathrm{C}$ for $90 \mathrm{~min}$, as described previously (29). Upon rinsing, anti-rabbit or anti-mouse horseradish peroxidase-conjugated secondary antibodies (dilution 1:100; Zymed Laboratories; Thermo Fisher Scientific, Inc.) were used to detect the primary antibodies. The sections were subsequently washed twice with PBS. The peroxidase reaction was developed with 3-amino-9-ethylcarbazole (Sigma-Aldrich; Merck Millipore) as a chromogen, and the sections were washed for $5 \mathrm{~min}$ in tap water and counterstained with hematoxylin. The IHC results were evaluated by two observers by semi-quantifying the percentage of immunopositivity of ten fields per slide, and 
Table I. Primary antibodies used in western blot analysis.

\begin{tabular}{|c|c|c|c|c|c|}
\hline Target & Type & Catalog no. & Host species/targeted species & Dilution & Secondary antibody \\
\hline$\beta$-actin & Monoclonal & A1978 & Mouse anti-human & $1: 3,000$ & Goat anti-mouse \\
\hline Bcl-2 & Polyclonal & sc-492 & Rabbit anti-human & $1: 200$ & Goat anti-rabbit \\
\hline Bax & Polyclonal & sc-493 & Rabbit anti-human & $1: 200$ & Goat anti-rabbit \\
\hline Survivin & Monoclonal & sc-17779 & Mouse anti-human & $1: 400$ & Goat anti-mouse \\
\hline Caspase-9 & Polyclonal & sc- -8355 & Rabbit anti-human & $1: 200$ & Goat anti-rabbit \\
\hline Procaspase-3 & Polyclonal & sc-7148 & Rabbit anti-human & $1: 400$ & Goat anti-rabbit \\
\hline Activated caspase-3 & Polyclonal & \#9662s & Rabbit anti-human & $1: 400$ & Goat anti-rabbit \\
\hline Fas & Polyclonal & sc-715 & Rabbit anti-human & $1: 400$ & Goat anti-rabbit \\
\hline FADD & Polyclonal & sc-5559 & Rabbit anti-human & $1: 400$ & Goat anti-rabbit \\
\hline Procaspase- 8 & Monoclonal & \#9746 & Mouse anti-human & $1: 400$ & Goat anti-mouse \\
\hline Cyclin E & Polyclonal & sc-481 & Rabbit anti-human & $1: 400$ & Goat anti-rabbit \\
\hline Cyclin A & Polyclonal & sc-751 & Rabbit anti-human & $1: 400$ & Goat anti-rabbit \\
\hline Cdk2 & Polyclonal & sc-163 & Rabbit anti-human & $1: 200$ & Goat anti-rabbit \\
\hline $\mathrm{p} 21$ & Polyclonal & sc-397 & Rabbit anti-human & $1: 400$ & Goat anti-rabbit \\
\hline p27 & Polyclonal & sc-527 & Rabbit anti-human & $1: 200$ & Goat anti-rabbit \\
\hline I $\kappa \mathrm{B}-\alpha$ & Polyclonal & sc-371 & Rabbit anti-human & $1: 500$ & Goat anti-rabbit \\
\hline $\mathrm{NF}-\kappa \mathrm{B} / \mathrm{p} 65$ & Polyclonal & sc-109 & Rabbit anti-human & $1: 500$ & Goat anti-rabbit \\
\hline Caspase-12 & Polyclonal & AB3613 & Rabbit anti-human & $1: 200$ & Goat anti-rabbit \\
\hline CK19 & Monoclonal & $a b 7754$ & Mouse anti-human & $1: 500$ & Goat anti-mouse \\
\hline PCNA & Monoclonal & NCL-L-PCNA & Mouse anti-human & $1: 500$ & Goat anti-mouse \\
\hline
\end{tabular}

Bcl, B-cell lymphoma; Bax, Bcl-2-like protein 4; FADD, Fas-associated death domain; Cdk, cyclin-dependent kinase; IкB- $\alpha$; inhibitor of $\kappa \mathrm{B}-\alpha$; $\mathrm{NF}$, nuclear factor; $\mathrm{CK}$, cytokeratin; PCNA, proliferating cell nuclear antigen.

Table II. Primary antibodies used in immunohistochemistry.

\begin{tabular}{llccrr}
\hline Target & Type & Catalog no. & Host species/targeted species & Dilution & Secondary antibody \\
\hline CK19 & Polyclonal & ab15463 & Rabbit anti-human & $1: 50$ & Goat anti-rabbit \\
PCNA & Monoclonal & NCL-L-PCNA & Mouse anti-human & $1: 50$ & Goat anti-mouse \\
Cyclin A & Polyclonal & sc-751 & Rabbit anti-human & $1: 50$ & Goat anti-rabbit \\
Bax & Polyclonal & ab7977 & Rabbit anti-human & $1: 100$ & Goat anti-rabbit \\
Bcl-2 & Polyclonal & sc-492 & Rabbit anti-human & $1: 50$ & Goat anti-rabbit \\
Caspase-9 & Polyclonal & ab2014 & Rabbit anti-human & $1: 100$ & Goat anti-rabbit \\
Caspase-3 & Polyclonal & ab44976 & Rabbit anti-human & $1: 100$ & Goat anti-rabbit \\
\hline
\end{tabular}

Bcl, B-cell lymphoma; Bax, Bcl-2-like protein 4; CK, cytokeratin; PCNA, proliferating cell nuclear antigen.

scored as $0 \%=$ negative, $<25 \%=1+, 25-50 \%=2+,>50-75 \%=3+$ and $>75 \%=4+$.

Histopathological study. The liver, kidney and stomach of hamsters from each group were fixed in $10 \%$ buffered formalin for $24 \mathrm{~h}$ and then embedded in paraffin wax. Sections of 4- $\mu \mathrm{m}$ thickness were stained with hematoxylin and eosin (H\&E) staining. The tissues slides were observed and photographed on a light microscope at x10 and x40 magnification (Eclipse Ni-U; Nikon Corporation).

Liver and kidney function assays. Plasma alanine aminotransferase (ALT) and alkaline phosphatase (ALP), markers of liver damage, as well as blood urea nitrogen (BUN) and creatinine levels were analyzed at the Chemistry Room, Community Laboratory, Faculty of Associated Medical Sciences, Khon Kaen University (Khon Kaen, Thailand) (30).

Statistical analysis. All the values are expressed as the mean \pm standard deviation. All data analysis was performed using SPSS 10.0 statistical software (SPSS, Inc., Chicago, IL, USA). Statistical comparisons of the results were evaluated using the Student's $t$-test. $\mathrm{P}<0.05$ was considered to indicate a statistically significant difference, and the statistical significance of the differences between the groups were indicated as ${ }^{*} \mathrm{P}<0.05,{ }^{* *} \mathrm{P}<0.01$ or ${ }^{* * *} \mathrm{P}<0.001$. 
Table III. Primer sequences used for reverse transcription-quantitative polymerase chain reaction.

\begin{tabular}{|c|c|c|c|c|}
\hline Gene & Primer sequences & $\begin{array}{l}\text { No. of } \\
\text { cycles }\end{array}$ & $\mathrm{Ta},{ }^{\circ} \mathrm{C}$ & $\begin{array}{c}\text { GenBank accession no. } \\
\text { (ref.) }\end{array}$ \\
\hline GAPDH & $\begin{array}{l}\text { Forward: 5'-GGCATTGTGGAAGGGCTCAT-3' } \\
\text { Reverse: 5'-GACACATTGGGGGTAGGAACAC-3' }\end{array}$ & 35 & 60 & (25) \\
\hline CK19 & $\begin{array}{l}\text { Forward: 5'-GCGGGACAAGATTCTTGGTG-3' } \\
\text { Reverse: 5'-CTTCAGGCCTTCGATCTGCAT-3 }\end{array}$ & 40 & 62 & NM_008471.2 \\
\hline $\operatorname{Bax}$ & $\begin{array}{l}\text { Forward: 5'-AGCTGCAGAGGATGATTGCT-3' } \\
\text { Reverse: 5'-CTCTCGGAGGAAGTCCAGTG-3' }\end{array}$ & 40 & 62 & (25) \\
\hline Apaf-1 & $\begin{array}{l}\text { Forward: 5'-ATCCTGGTGCTTTGCCTCTA-3' } \\
\text { Reverse: 5'-TACACCCCCTGAAAAGCAAC-3' }\end{array}$ & 50 & 62 & (26) \\
\hline Caspase-9 & $\begin{array}{l}\text { Forward: 5'-CTGCACTTCCTCTCAAGGCA-3 } \\
\text { Reverse: 5'-GAAACAGCATTGGCGACCTG-3' }\end{array}$ & 40 & 52 & XM_005139261.1 \\
\hline Caspase-3 & $\begin{array}{l}\text { Forward: 5'-TTCGAGCCACCGAGGAGATA-3' } \\
\text { Reverse: 5'-TTGGGGACATCATCCACACG-3' }\end{array}$ & 40 & 54 & NM_001281582.1 \\
\hline
\end{tabular}

Ta, annealing temperature; CK, cytokeratin; Bax, B-cell lymphoma-2-like protein 4; Apaf, apoptotic protease activating factor.
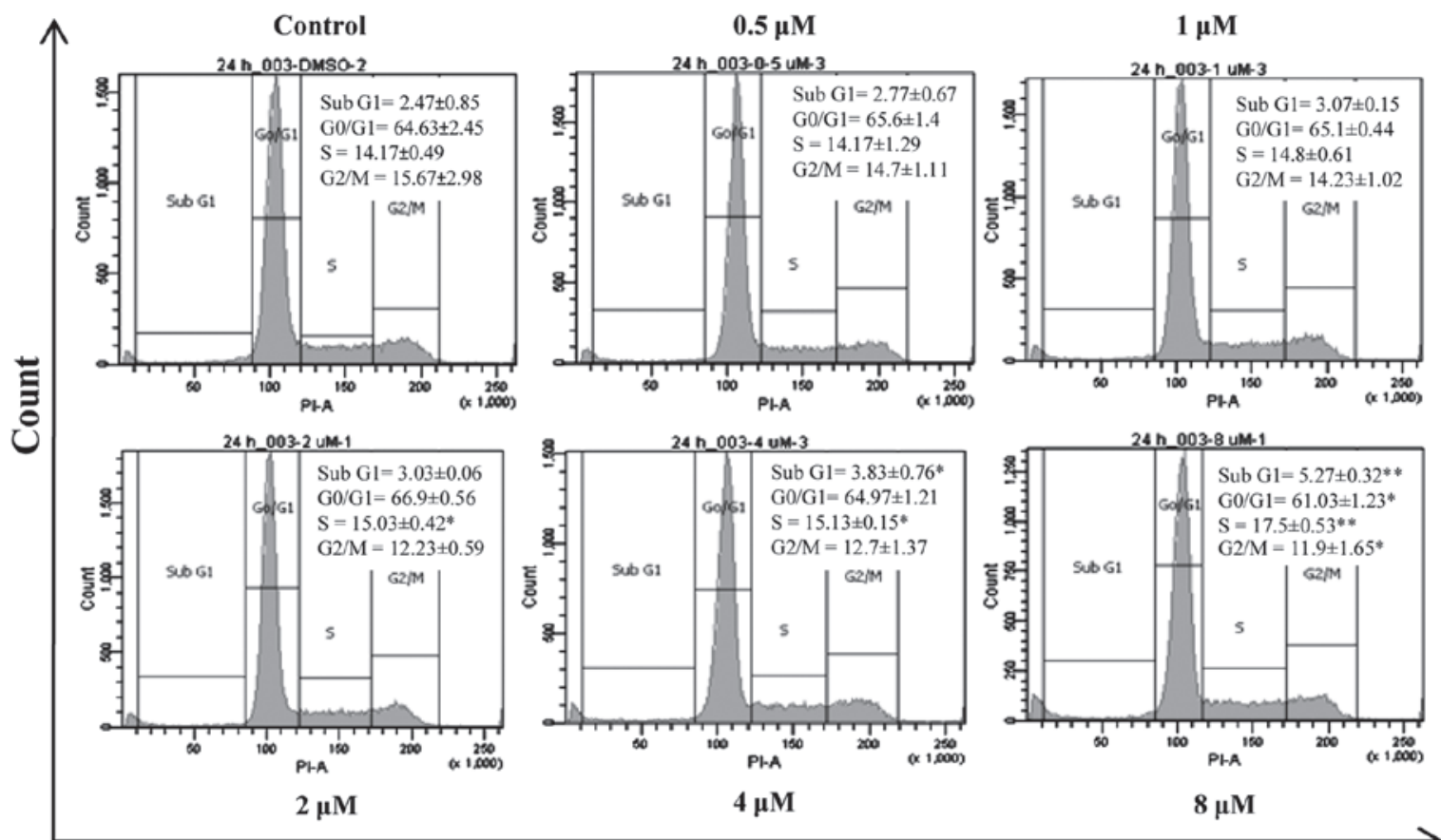

DNA content

Figure 2. Dose-dependent effect of forbesione on the cell cycle distribution of cultured Ham-1 cells. Cell cycle histogram of Ham-1 cells treated with different concentrations of forbesione $(0,0.5,1,2,4$ and $8 \mu \mathrm{M})$ for $24 \mathrm{~h}$. Data are presented as the mean \pm standard deviation of three independent experiments. " $\mathrm{P}<0.05$, ${ }^{* *} \mathrm{P}<0.01$. PI-A, propoidum iodide-area; DMSO, dimethyl sulfoxide.

\section{Results}

Forbesione inhibits the proliferation of Ham-1 cells in vitro. Treatment of Ham-1 cells with forbesione inhibited cell proliferation in a concentration-dependent manner, with a half maximal inhibitory concentration value of $3.21 \pm 0.27 \mu \mathrm{M}$.

Forbesione induces S-phase cell cycle arrest in Ham-1 cells. Since forbesione significantly reduced Ham-1 cell numbers after $24 \mathrm{~h}$, the effects of forbesione at $0.5,1,2,4$ and $8 \mu \mathrm{M}$ on the cell cycle progression of Ham-1 cells were determined. The results revealed that Ham-1 cells became arrested in the $\mathrm{S}$ phase $(\mathrm{P}<0.01)$ in response to forbesione treatment in a concentration-dependent manner, concomitant with a reduction in the proportion of cells in the $G_{0} / G_{1}(P<0.05)$ and $\mathrm{G}_{2} / \mathrm{M}(\mathrm{P}<0.05)$ phases (Fig. 2). In addition, the percentage of Ham-1 cells in the sub- $G_{1}$ fraction (apoptotic cells) was significantly increased in a concentration-dependent manner $(\mathrm{P}<0.01)$. These results support that forbesione induces a growth-inhibitory effect, cell cycle arrest and apoptosis. 
A

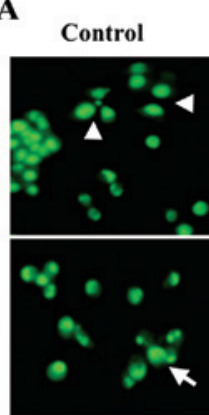

Forb $8 \mu \mathrm{M}$

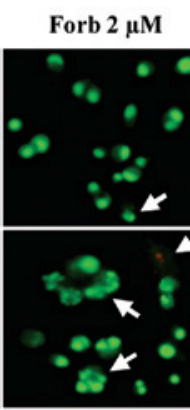

Forb $16 \mu \mathrm{M}$

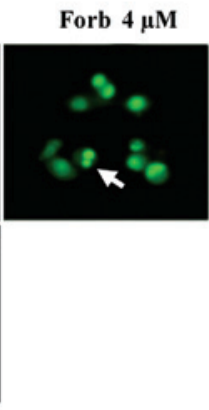

$\mathbf{C}$

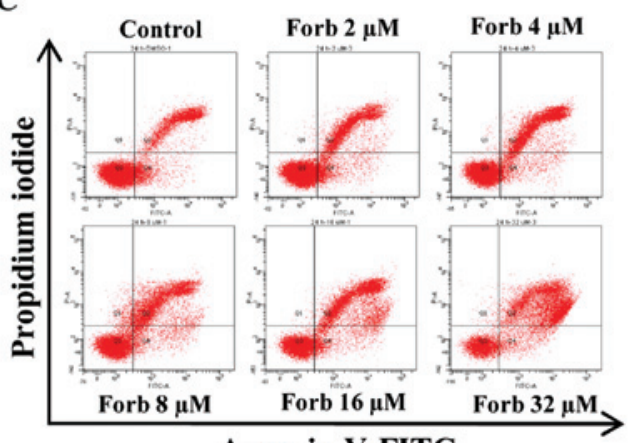

Annexin V-FITC

E

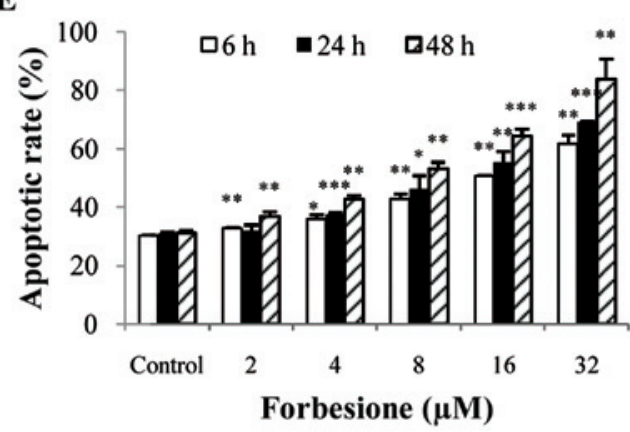

B

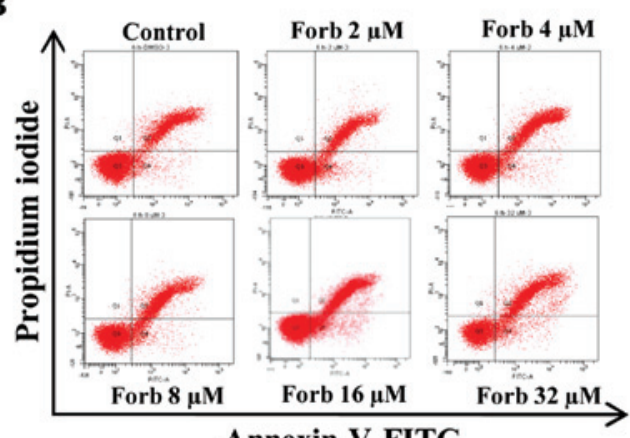

Annexin V-FITC

D

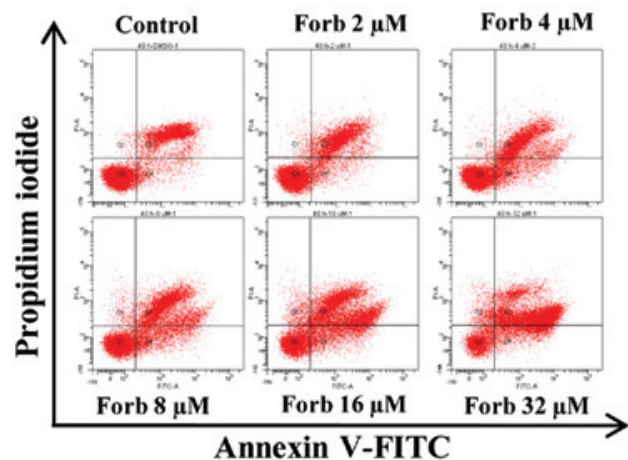

Figure 3. Apoptotic effect in Ham-1 cells following treatment with forbesione. (A) Nuclear morphological change of Ham-1 cells treated with different concentrations of forbesione $(0,2,4,8,16$ and $32 \mu \mathrm{M})$ for $24 \mathrm{~h}$ followed by ethidium bromide/acridine orange staining (magnification, $\mathrm{x} 40)$. Nuclei of living cells were uniformly stained green (arrowheads). Early apoptotic cells exhibited condensed and fragmented chromatin (arrows). Flow cytometric analysis of the induction of apoptosis in Ham-1 cells following treatment with forbesione (0,2, 4, 8, 16 and $32 \mu \mathrm{M})$ for (B) 6 , (C) 24 and (D) 48 h. (E) Graph of the percentage of apoptotic cells for the indicated concentrations at different times. Data are presented as the mean \pm standard deviation of three separate experiments. ${ }^{*} \mathrm{P}<0.05,{ }^{* *} \mathrm{P}<0.01,{ }^{* * *} \mathrm{P}<0.001$. Forb, forbesione; FITC, fluorescein isothiocyanate.

Forbesione induces changes in the nuclear morphology of Ham-1 cells. As forbesione significantly increased the sub- $\mathrm{G}_{1}$ fraction, nuclear morphological features of apoptosis were assessed in Ham-1 cells treated with various concentrations of forbesione for $24 \mathrm{~h}$ followed by EB/AO staining. The results indicated that the untreated cells displayed normal nuclear shapes that stained uniformly green, whereas the treated cells exhibited bright green, condensed and fragmented chromatin (Fig. 3A), which are the hallmarks of apoptosis (31).

Forbesione increases the percentage of Ham-1 cells undergoing apoptosis. Ham-1 cells were treated with $0.1 \%$ DMSO or with $2,4,8,16$ or $32 \mu \mathrm{M}$ forbesione for 6,24 and $48 \mathrm{~h}$, and then the percentages of apoptotic cells were determined by annexin V-FITC/PI staining. The flow cytometry results revealed that the proportions of cells undergoing apoptosis were significantly increased by forbesione in a concentration- and time-dependent manner (Fig. 3B-E). Treatment with
$32 \mu \mathrm{M}$ forbesione for 6,24 and $48 \mathrm{~h}$ resulted in $50.75(\mathrm{P}<0.01)$, $55.57(\mathrm{P}<0.001)$ and $64.43 \%(\mathrm{P}<0.001)$ apoptotic cells, respectively (Fig. 3E).

Forbesione alters the expression of proteins regulating the cell cycle and apoptosis. As forbesione induced cell cycle arrest at the $\mathrm{S}$ phase, western blot analysis was used to investigate the expression of proteins involved in cell cycle regulation at the $\mathrm{S}$ phase in Ham-1 cells treated with $0.1 \%$ DMSO or with 2,4 or $8 \mu \mathrm{M}$ forbesione for $24 \mathrm{~h}$. The results demonstrated that cyclin E, cyclin A and Cdk2 levels were significantly decreased $(\mathrm{P}<0.01, \mathrm{P}<0.05$ and $\mathrm{P}<0.01$, respectively), while p21 and p27 levels were significantly increased $(\mathrm{P}<0.05)$, in forbesione-treated cells compared with those in the control cells (Fig. 4A).

Apoptosis is triggered by multiple pathways, including the extrinsic, intrinsic and ER pathways (32). The extrinsic pathway is regulated by the activation of death receptors on 
A

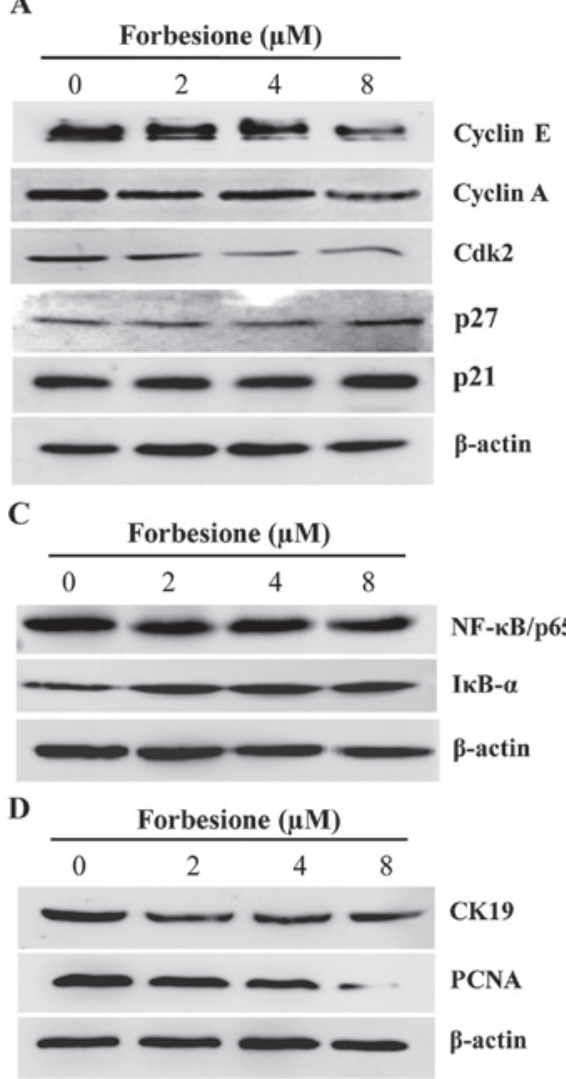

B

\begin{tabular}{cccc}
\multicolumn{3}{c}{ Forbesione $(\boldsymbol{\mu M})$} \\
\hline 0 & 2 & 4 & 8
\end{tabular}
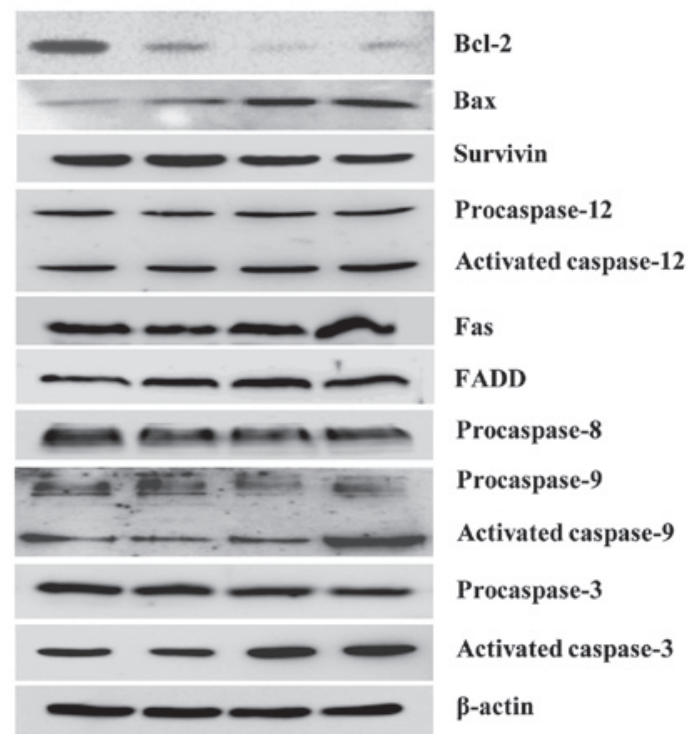

Fas

FADD

Procaspase-8

Procaspase-9

Activated caspase-9

Procaspase-3

Activated caspase-3

$\beta$-actin

Figure 4. Expression of proteins associated with the regulation of cell cycle arrest, apoptosis and growth inhibition in forbesione-treated cells. (A) Representative western blot analysis of cell lysates after being treated with forbesione $(0,2,4$ and $8 \mu \mathrm{M})$ for $24 \mathrm{~h}$; the expression of cell cycle-regulatory proteins was decreased. (B) Compared with the control group, the expression of apoptotic-regulatory molecules changed (increased or decreased) in the forbesione-treated

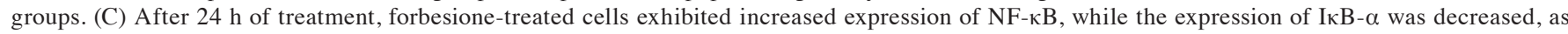
compared with that in the control group. (D) Compared with the control group, the expression of CK19 and PCNA proteins was decreased following treatment with forbesione. Bcl, B-cell lymphoma; Bax, Bcl-2-like protein 4; FADD, Fas-associated death domain; Cdk, cyclin-dependent kinase; IкB- $\alpha$; inhibitor of $\kappa \mathrm{B}-\alpha$; NF, nuclear factor; $\mathrm{CK}$, cytokeratin; PCNA, proliferating cell nuclear antigen.

the cell surface such as Fas (also known as apoptosis antigen-1 and cluster of differentiation 95) (33), which will activate downstream signal transduction molecules, including FADD, procaspase- 8 and procaspase- 3 , subsequently leading to apoptotic cell death (34). Treatment of Ham-1 cells with $0.1 \%$ DMSO or with 2, 4 or $8 \mu \mathrm{M}$ forbesione for $24 \mathrm{~h}$ significantly increased the level of Fas, FADD and activated caspase-3 $(\mathrm{P}<0.05)$, while that of procaspase- 8 and procaspase- 3 was significantly decreased $(\mathrm{P}<0.05$ and $\mathrm{P}<0.01$, respectively; Fig. 4B). These findings suggest that forbesione induces apoptosis possibly through the Fas signaling pathway.

The intrinsic pathway is controlled by the Bcl-2 family of proteins, including pro-apoptotic proteins such as Bax and Bak, and anti-apoptotic proteins such as Bcl-2, which leads to the activation of procaspase- 9 and procaspase- 3 and subsequently apoptotic cell death (35). In the present study, forbesione treatment significantly decreased the expression of $\mathrm{Bcl}-2$, procaspase $9(\mathrm{P}<0.05)$ and procaspase $3(\mathrm{P}<0.01)$, while significantly increasing the expression of Bax, activated caspase- 9 and activated caspase- 3 ( $\mathrm{P}<0.05$; Fig. 4B), suggesting that forbesione-induced apoptosis is mediated in part through the intrinsic mitochondrial pathway.

Upon encountering ER stress, $\mathrm{Ca}^{2+}$ efflux from the ER will activate the calcium-dependent protease m-calpain, which activates procaspase-12 and subsequently activates procaspase- 9 and procaspase- 3 , thereby driving apoptotic cell death $(36,37)$. Forbesione treatment of Ham-1 cells significantly decreased the protein level of procaspase-12, procaspase- 9 and procaspase- $3(\mathrm{P}<0.05, \mathrm{P}<0.05$ and $\mathrm{P}<0.01$, respectively), while significantly increasing the protein level of activated caspase-12, activated caspase- 9 and activated caspase-3 ( $\mathrm{P}<0.05$; Fig. 4B), suggesting that the induction of apoptosis occurs through the ER pathway.

$\mathrm{NF}-\mathrm{\kappa B}$ is a nuclear factor known to activate the expression of genes involved in cell survival (anti-apoptotic proteins such as $\mathrm{Bcl}-2$ and survivin), and NF- $\mathrm{KB}$ activation is regulated by IкB- $\alpha(38,39)$. The present results indicated that forbesione treatment significantly decreased $\mathrm{NF}-\kappa \mathrm{B} / \mathrm{p} 65$ expression $(\mathrm{P}<0.01)$ while significantly increasing $\mathrm{I} \kappa \mathrm{B}-\alpha$ expression $(\mathrm{P}<0.05 ;$ Fig. 4C). These results support that the inhibition of $\mathrm{NF}-\mathrm{\kappa B}$ activation by forbesione is possibly mediated through decreased NF- $\kappa \mathrm{B}$ expression and increased IкB- $\alpha$ expression, leading to reduced expression of Bcl-2 and survivin.

Forbesione decreases expression of CK19 and PCNA proteins in Ham-1 cells in vitro. To further assess the changes during the growth inhibition induced by forbesione, the expression of CK19 and PCNA proteins in Ham-1 cells treated with $0.1 \%$ DMSO or with 2,4 or $8 \mu \mathrm{M}$ forbesione for $24 \mathrm{~h}$ was determined by western blot analysis. The results revealed that the 

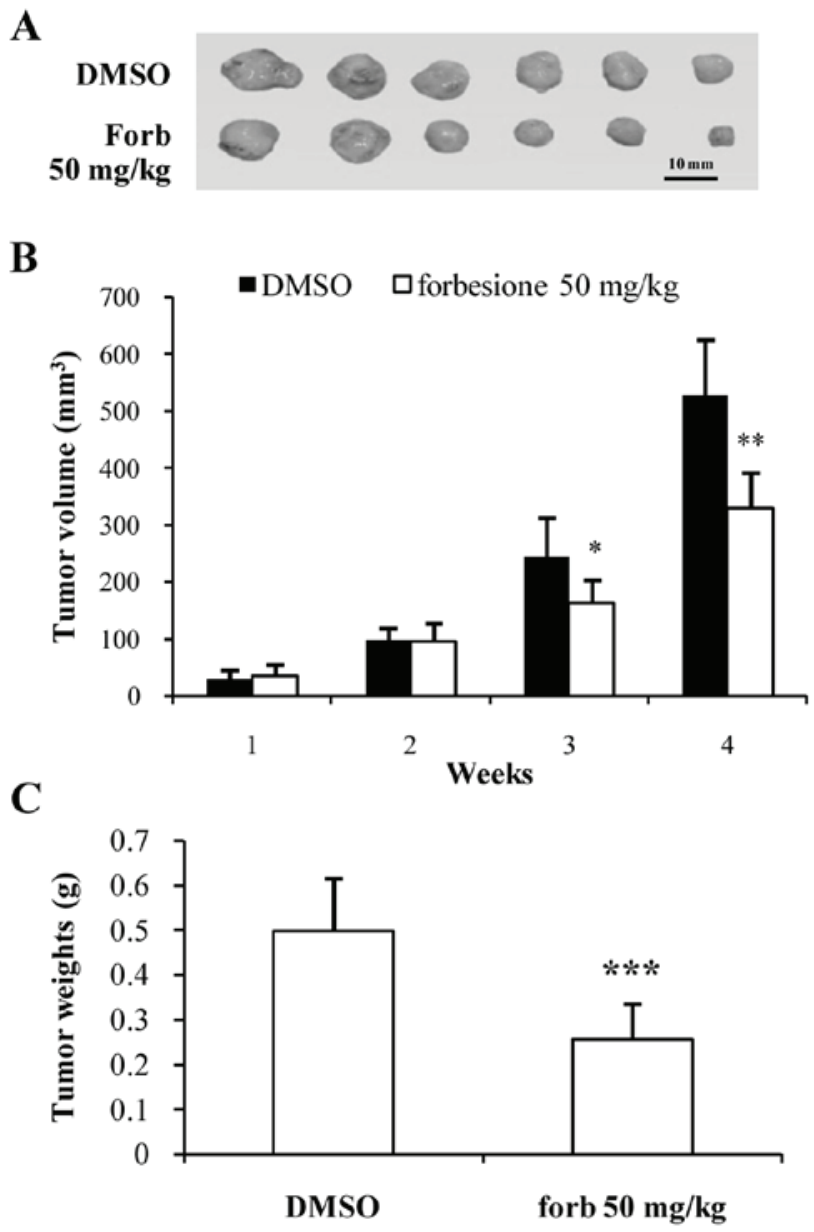

Figure 5. Inhibitory effects of forbesione on Ham-1 cell allografts. (A) Tumor allografts were isolated from treated and control groups following intradermal injection of Ham-1 cells. After 4 weeks of forbesione treatment, the antitumor activity was evaluated according to (B) tumor volume and (C) tumor weight measurements. Data are presented as the mean \pm standard deviation. ${ }^{*} \mathrm{P}<0.05$, ${ }^{* *} \mathrm{P}<0.01,{ }^{* *} \mathrm{P}<0.001$. Forb, forbesione; DMSO, dimethyl sulfoxide.

CK19 and PCNA protein levels were significantly decreased in forbesione-treated cells $(\mathrm{P}<0.01$ and $\mathrm{P}<0.05$, respectively) compared with those in the control cells (Fig. 4D).

Forbesione suppresses tumor growth in the Ham-1 allograft hamster model. To determine the effect of forbesione on the growth of CCA in vivo, Ham-1 cells were injected intradermally in the flanks of Syrian hamsters. Tumors were allowed to establish for 3 days prior to administration of forbesione (50 $\mathrm{mg} / \mathrm{kg} /$ day orally for 4 weeks). The control group received the same volume of diluent control (1\% DMSO in $1 \%$ FBS-DMEM). Forbesione treatment reduced the tumor size (Fig. 5A), volume ( $\mathrm{P}<0.01$; Fig. $5 \mathrm{~B})$ and weight $(\mathrm{P}<0.001$; Fig. 5C) when compared to the control group. The mean tumor weight of the forbesione-treated group $(0.27 \mathrm{~g})$ was significantly lower than that of the control group $(0.54 \mathrm{~g})$.

Forbesione decreases the relative level of CK19 mRNA while increasing that of Bax, Apaf-1, caspase-9 and caspase-3 in tumor allografts. To investigate the mechanisms of tumor growth suppression mediated by forbesione, the relative changes in CK19, Bax, Apaf-1, caspase-9 and caspase-3 mRNA were assessed in tumor tissues derived from the control and forbesione-treated groups by RT-qPCR. The relative expression of CK19 mRNA was significantly decreased, while that of Bax, Apaf-1, caspase-9 and caspase-3 was significantly increased in the tumor tissues from the forbesione-treated group as compared with those in the control group $(\mathrm{P}<0.05$; Fig. 6A). These findings support that apoptosis induction by forbesione leads to reduced expression of CK19 [a marker of bile duct epithelial cells (40)] (Fig. 6A).

Forbesione decreases the expression of CK19, PCNA, cyclin A and Bcl-2 proteins, and increases the expression of Bax, caspase- 9 and caspase-3 proteins in tumor allografts. To further assess the changes during the suppression of tumor growth mediated by forbesione, the allograft tissues derived from the control and forbesione-treated groups were IHC stained for CK19, PCNA, an S-phase cell cycle-regulated protein (cyclin A) and apoptosis-related proteins (Bcl-2, Bax, caspase-9 and caspase-3). Semi-quantitative IHC scores were analyzed. As compared with the control allograft group, allografts from the forbesione-treated hamsters had significantly decreased expression of CK19 $(\mathrm{P}=0.036), \mathrm{PCNA}$ $(\mathrm{P}=0.032)$, cyclin $\mathrm{A}(\mathrm{P}=0.028)$ and $\mathrm{Bcl}-2(\mathrm{P}=0.039)$, with significantly increased expression of $\mathrm{Bax}(\mathrm{P}=0.039)$, caspase-9 $(\mathrm{P}=0.028)$ and caspase-3 $(\mathrm{P}=0.039)$ (Fig. 6B and $\mathrm{C}$ and Table IV). These results corroborate our in vitro study in which forbesione suppressed tumor growth partly through cell cycle arrest (by decreasing the abundance of the cell cycle regulatory protein cyclin A) and through induction of apoptosis (by modulating the expression of apoptosis-related proteins).

Forbesione has no side effects in hamsters. To assess whether forbesione has side effects on treated hamsters, several parameters were determined, including physical activity, body weight, histopathological changes within the liver, kidney and stomach, and liver and kidney function tests. During 4 weeks of experiments, the physical activities were observed, and the body weight, food intake and water intake were measured daily. The forbesione-treated hamsters were healthy, with no changes in normal physical activities as compared with the control group. In the forbesione-treated group, the body weight, food and water intake were significantly increased as compared with those in the control hamsters $(\mathrm{P}<0.001$, $\mathrm{P}<0.001$ and $\mathrm{P}<0.05$, respectively; Fig. 7A-C).

At the end of the treatment, H\&E-stained sections of the liver, kidney and stomach of the control and forbesione-treated hamsters were evaluated by two investigators without knowledge of the treatment status. Semi-quantitative analysis was performed to assess inflammatory cell aggregates surrounding the hepatic bile ducts and present in the liver, kidney and stomach (forestomach and glandular stomach) tissues. The histopathological changes of the liver (Fig. 7D and Table V), kidney (Fig. 7E and Table VI) and stomach (Fig. 7F and Table VII) of the forbesione-treated hamsters were not significantly different from those of the control hamsters.

The sera collected from the control and forbesione-treated hamsters at the end of the experiment were used to determine the liver and kidney functions. The levels of liver serum 
Table IV. Effect of forbesione on IHC scores for the expression of CK19, PCNA, cyclin A, Bcl-2, Bax, caspase-9 and caspase-3 in allograft tissues.

\begin{tabular}{|c|c|c|c|c|c|c|c|}
\hline \multirow[b]{2}{*}{ Antigen } & \multirow[b]{2}{*}{ Groups } & \multicolumn{5}{|c|}{ IHC score } & \multirow[b]{2}{*}{ P-value } \\
\hline & & $\begin{array}{c}0 \\
\mathrm{n}(\%)\end{array}$ & $\begin{array}{c}1 \\
\text { n }(\%)\end{array}$ & $\begin{array}{c}2 \\
\mathrm{n}(\%)\end{array}$ & $\begin{array}{c}3 \\
\mathrm{n}(\%)\end{array}$ & $\begin{array}{c}4 \\
\mathrm{n}(\%)\end{array}$ & \\
\hline \multirow[t]{2}{*}{ CK19 } & Control & $0(0)$ & $0(0)$ & $1(25)$ & $1(25)$ & $2(50)$ & \\
\hline & Forbesione $(50$ mg/kg) & $0(0)$ & $1(25)$ & $2(50)$ & $1(25)$ & $0(0)$ & $0.036^{\mathrm{a}}$ \\
\hline \multirow[t]{2}{*}{ PCNA } & Control & $0(0)$ & $0(0)$ & $1(25)$ & $3(75)$ & $0(0)$ & \\
\hline & Forbesione $(50 \mathrm{mg} / \mathrm{kg})$ & $0(0)$ & $2(50)$ & $2(50)$ & $0(0)$ & $0(0)$ & $0.032^{\mathrm{a}}$ \\
\hline \multirow[t]{2}{*}{ Cyclin A } & Control & $0(0)$ & $0(0)$ & $0(0)$ & $1(25)$ & $3(75)$ & \\
\hline & Forbesione $(50 \mathrm{mg} / \mathrm{kg})$ & $0(0)$ & $0(0)$ & $3(75)$ & $1(25)$ & $0(0)$ & $0.028^{\mathrm{a}}$ \\
\hline \multirow[t]{2}{*}{ Bcl-2 } & Control & $0(0)$ & $0(0)$ & $2(50)$ & $0(0)$ & $2(50)$ & \\
\hline & Forbesione $(50 \mathrm{mg} / \mathrm{kg})$ & $0(0)$ & $1(25)$ & $3(75)$ & $0(0)$ & $0(0)$ & $0.039^{\mathrm{a}}$ \\
\hline \multirow[t]{2}{*}{$\operatorname{Bax}$} & Control & $0(0)$ & $1(25)$ & $2(50)$ & $0(0)$ & $1(25)$ & \\
\hline & Forbesione $(50 \mathrm{mg} / \mathrm{kg})$ & $0(0)$ & $0(0)$ & $0(0)$ & $2(50)$ & $2(50)$ & $0.039^{\mathrm{a}}$ \\
\hline \multirow[t]{2}{*}{ Caspase-9 } & Control & $0(0)$ & $0(0)$ & $2(50)$ & $1(25)$ & $1(25)$ & \\
\hline & Forbesione $(50 \mathrm{mg} / \mathrm{kg})$ & $0(0)$ & $0(0)$ & $0(0)$ & $2(50)$ & $2(50)$ & $0.028^{\mathrm{a}}$ \\
\hline \multirow[t]{2}{*}{ Caspase-3 } & Control & $0(0)$ & $1(25)$ & $2(50)$ & $0(0)$ & $1(25)$ & \\
\hline & Forbesione $(50 \mathrm{mg} / \mathrm{kg})$ & $0(0)$ & $0(0)$ & $1(25)$ & $0(0)$ & $3(75)$ & $0.039^{\mathrm{a}}$ \\
\hline
\end{tabular}

The CK19, PCNA, cyclin A, Bcl-2, Bax, caspase-9 and caspase-3 IHC results are represented as follows: 0 , completely negative; $1,<25 \%$ of CCA area (faint positivity); $2,25-50 \%$ of CCA area (moderate positivity); 3, $>50-75 \%$ of CCA area (strong positivity); and $4,>75 \%$ of CCA area (extremely strong positivity). a Significant difference between control and treatment group $(\mathrm{P}<0.05)$. IHC, immunohistochemical; CCA, cholangiocarcinoma; CK, cytokeratin; PCNA, proliferating cell nuclear antigen; Bcl, B-cell lymphoma; Bax, Bcl-2-like protein 4.

A

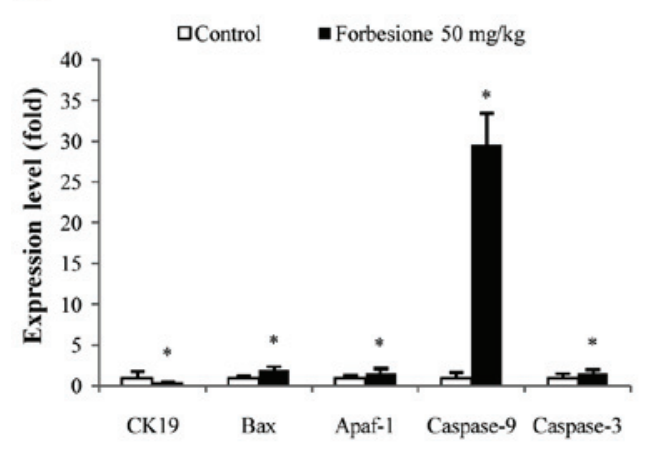

B

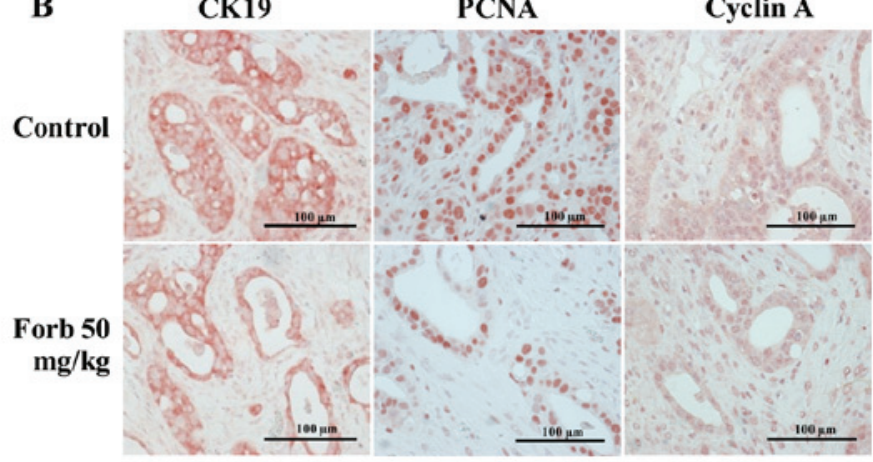

Bcl-2

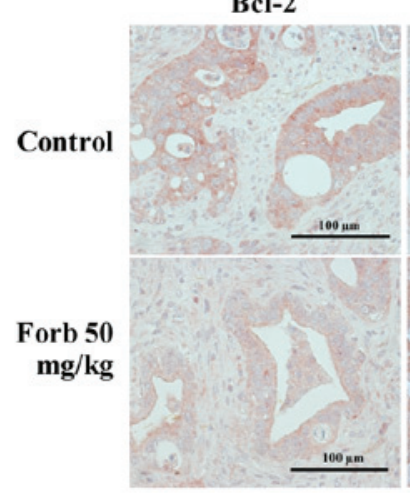

Bax

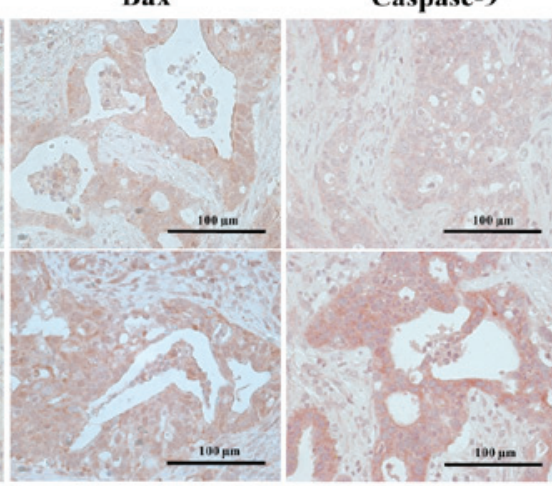

Caspase-9

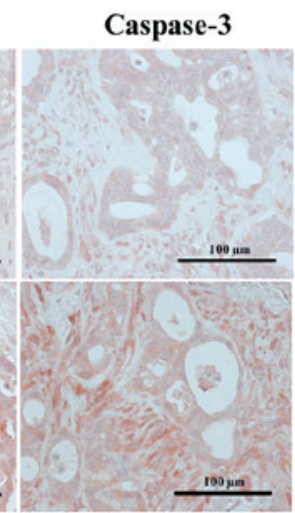

Figure 6. Expression changes in genes and/or proteins associated with the regulation of cell cycle and cell apoptosis (epithelial bile duct marker CK19 and proliferation marker PCNA). (A) Compared with the control group, the gene expression of CK19 significantly decreased, while the gene expression of Bax, Apaf-1, caspase- 9 and caspase- 3 significantly increased, in the forbesione-treated group. Data are presented as the mean \pm standard deviation. ${ }^{*} \mathrm{P}<0.05$. (B and C) Representative immunohistochemical staining of Ham-1 allograft tissue (magnification, x40). Compared with the control group, the protein expression of (B) CK19, PCNA, cyclin A and (C) Bcl-2 was decreased, while the protein expression of (C) Bax, caspase-9 and caspase-3 was increased, in the forbesione-treated group. Forb, forbesione; Apaf, apoptotic protease activating factor; Bcl, B-cell lymphoma; Bax, Bcl-2-like protein 4; CK, cytokeratin; PCNA, proliferating cell nuclear antigen. 

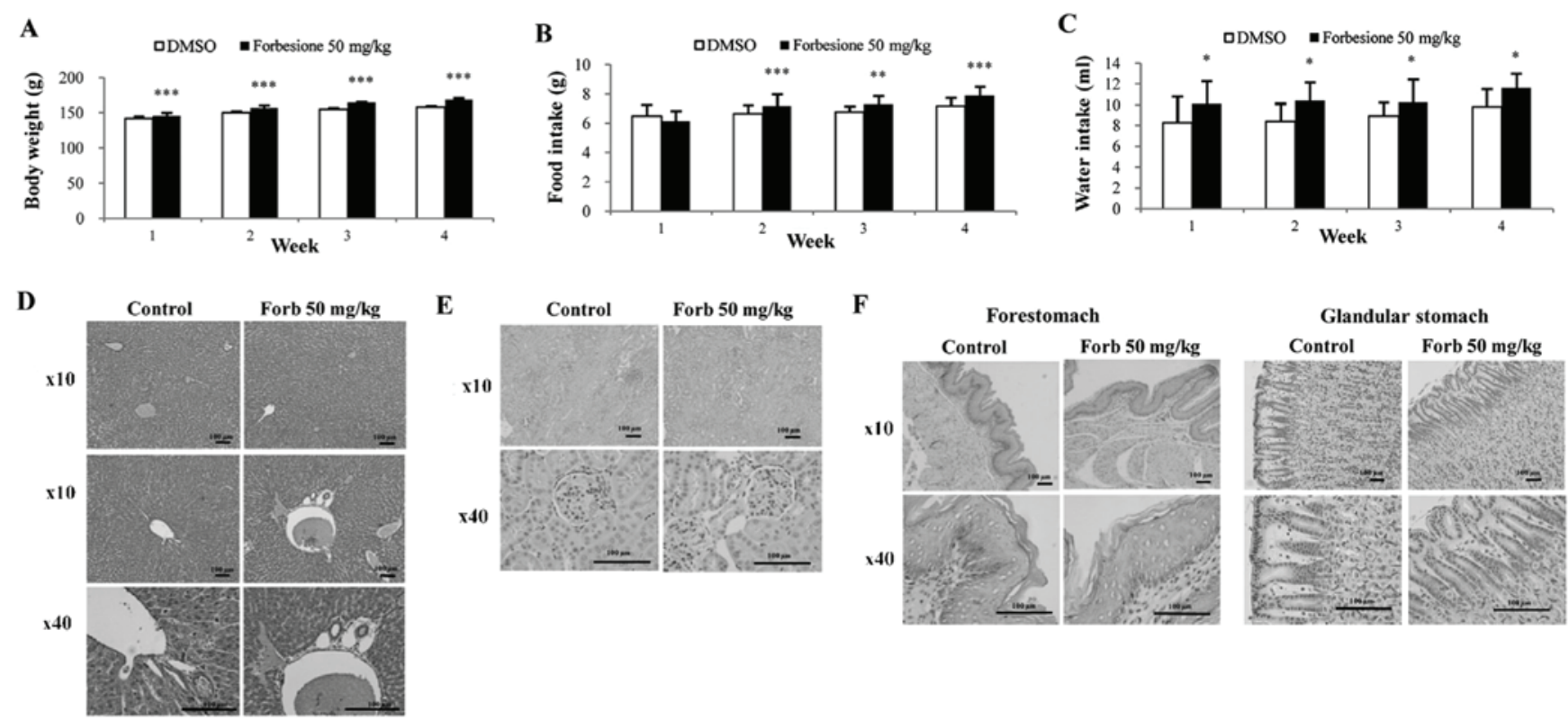

Figure 7. Effect of forbesione administration on the general parameters and histopathological assessment of inflammation in a hamster model. Effects of oral forbesione administration on (A) body weight, (B) food intake and (C) water intake. Compared with the control group, body weight, food intake and water intake were significantly increased in the forbesione-treated group. Values are presented as the mean \pm standard deviation. ${ }^{*} \mathrm{P}<0.05,{ }^{* * *} \mathrm{P}<0.01,{ }^{* * * *} \mathrm{P}<0.001$. Representative hematoxylin and eosin staining of the (D) liver, (E) kidney and (F) stomach (forestomach and glandular stomach) of hamsters following forbesione administration for 4 weeks. Forb, forbesione; DMSO, dimethyl sulfoxide.

markers (ALT and ALP) and kidney serum markers (BUN and creatinine) in the forbesione-treated group were similar to those observed in the control group (Table VIII), indicating no toxic effects of forbesione on the liver or kidney in the study.

\section{Discussion}

Forbesione, an active caged xanthone extracted from the resin of G. hanburyi, has been reported to have a growth-inhibitory effect against several cancer cell lines, including CCA cell lines $(6,9)$. Forbesione selectively inhibited cancer cell growth with no effect on normal human peripheral blood mononuclear cells (6). Recently, our group has reported that forbesione induced apoptosis in CCA cell lines through the intrinsic mitochondrial pathway (6). A synergistic effect of forbesione was observed with doxorubicin on the induction of apoptosis in human CCA cell lines (22). In the present study, the growth-inhibitory effect of forbesione on Ham-1 cells was investigated in vitro and in vivo in allografts, and the molecular mechanisms were also clarified. It was observed that forbesione significantly inhibited Ham-1 cell growth in vitro and suppressed allograft growth in vivo.

Previous studies demonstrated that gambogic acid, another caged xanthone isolated from $G$. hanburyi, causes cell cycle arrest at different phases in different tumor cells (41). For example, gambogic acid induces $\mathrm{G}_{0} / \mathrm{G}_{1}$ cell cycle arrest in the human CCA cell lines KKU-100 and KKU-M156 (21), as well as $\mathrm{G}_{2} / \mathrm{M}$ cell cycle arrest in breast carcinoma MCF-7 cells (42). Consistent with previous studies, forbesione was observed to inhibit Ham-1 cell proliferation by causing S-phase cell cycle arrest.
In eukaryotic cells, cell cycle progression is regulated by Cdks and cyclins (43). The formation of cyclin-Cdk complexes results in Cdk activation leading to the phosphorylation of substrates involved in cell cycle progression (44). Transition from the $\mathrm{G}_{1}$ to $\mathrm{S}$ phase is regulated by cyclin E-Cdk2 complexes, while the $\mathrm{S}$ phase is regulated by cyclin A-Cdk2 complexes (44). Cdk inhibitor proteins such as p21 and p27 can bind to the cyclin-Cdk complexes, resulting in an inhibition of kinase activity and prevention of cell cycle progression (45).

PCNA is involved in DNA repair, DNA replication and cell cycle regulation (46). PCNA is a transducer and a target of positive and negative signals (46). Binding of PCNA to cyclin-Cdk complexes may bring these regulatory proteins to the targets and promote cell proliferation, whereas binding of p21 to PCNA prevents PCNA from binding to the cell cycle or DNA replication machinery, thus leading to inhibition of DNA replication and cell cycle arrest (46). Our in vitro study demonstrated that the decreased expression of cyclin E, cyclin A and Cdk2 that occurred with increased expression of p21 and p27 could be a possible explanation for Ham-1 cells undergoing S-phase cell cycle arrest in response to forbesione. These results are partly confirmed by our in vivo study, in which forbesione treatment decreased the expression of cyclin $\mathrm{A}$ in tumor allograft tissues. In addition, the expression of PCNA and CK19 in forbesione-treated Ham-1 cells in vitro and tumor tissues from forbesione-treated hamsters was decreased compared with that in the control group. This may possibly be due to high levels of p21 in forbesione-treated cells causing downregulation of PCNA, which results in decreased tumor cell proliferation (47). The present results are consistent with those of our previous study (21), which demonstrated that the isomorellin-induced $G_{0} / G_{1}$ phase cell cycle arrest of human $\mathrm{CCA}$ cell lines is mediated through inhibition of NF- $\mathrm{KB}$ 
Table V. Histopathological features of liver tissues and grading criteria level in each experimental group.

\begin{tabular}{|c|c|c|c|}
\hline \multirow[b]{2}{*}{ Histopathology } & \multirow[b]{2}{*}{ Score } & \multicolumn{2}{|c|}{ Experimental groups } \\
\hline & & $\begin{array}{c}\text { Control, } \\
\mathrm{n}=6 \\
\mathrm{n}(\%)\end{array}$ & $\begin{array}{c}\text { Forbesione } \\
50 \mathrm{mg} / \mathrm{kg}, \\
\mathrm{n}=6 \\
\mathrm{n}(\%)\end{array}$ \\
\hline \multirow[t]{5}{*}{ Periportal inflammation $^{a}$} & 0 & $5(83.3)$ & $5(83.3)$ \\
\hline & 1 & $1(16.7)$ & $1(16.7)$ \\
\hline & 2 & $0(0.0)$ & $0(0.0)$ \\
\hline & 3 & $0(0.0)$ & $0(0.0)$ \\
\hline & 4 & $0(0.0)$ & $0(0.0)$ \\
\hline \multirow[t]{5}{*}{ Focal inflammation ${ }^{\mathrm{b}}$} & 0 & $5(83.3)$ & $6(100.0)$ \\
\hline & 1 & $1(16.7)$ & $0(0.0)$ \\
\hline & 2 & $0(0.0)$ & $0(0.0)$ \\
\hline & 3 & $0(0.0)$ & $0(0.0)$ \\
\hline & 4 & $0(0.0)$ & $0(0.0)$ \\
\hline
\end{tabular}

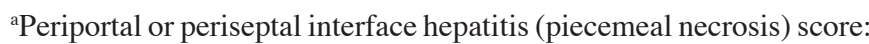
0 , none; 1 , mild (focal, few portal areas); 2 , mild/moderate (focal, the majority of portal areas); 3 , moderate (continuous around $<50 \%$ of tracts or septa); and 4 , severe (continuous around $>50 \%$ of tracts or septa). $\mathrm{P}=1.00$. $^{\mathrm{b}}$ Focal inflammation score: 0 , none; $1, \leq 1$ focus/X10 objective; 2, 2-4 foci/X10 objective; 3, 2-4 foci/X10 objective; and 4, 2-4 foci/X10. $\mathrm{P}=0.182$.

Table VI. Histopathological features of kidney tissues and grading criteria level in each experimental group.

\begin{tabular}{|c|c|c|c|}
\hline \multirow[b]{2}{*}{ Histopathology } & \multirow[b]{2}{*}{ Score } & \multicolumn{2}{|c|}{ Experimental groups } \\
\hline & & $\begin{array}{c}\text { Control, } \\
\mathrm{n}=6 \\
\mathrm{n}(\%)\end{array}$ & $\begin{array}{c}\text { Forbesione } \\
50 \mathrm{mg} / \mathrm{kg}, \\
\mathrm{n}=6 \\
\mathrm{n}(\%)\end{array}$ \\
\hline \multirow[t]{5}{*}{ Inflammation $^{\mathrm{a}}$} & 0 & $6(100.0)$ & $6(100.0)$ \\
\hline & 1 & $0(0.0)$ & $0(0.0)$ \\
\hline & 2 & $0(0.0)$ & $0(0.0)$ \\
\hline & 3 & $0(0.0)$ & $0(0.0)$ \\
\hline & 4 & $0(0.0)$ & $0(0.0)$ \\
\hline
\end{tabular}

${ }^{\mathrm{a}}$ Kidney inflammation score: 0 , none; $1, \leq 1$ focus/X10 objective; 2 , 2-4 foci/X10 objective; 3, 2-4 foci/X10 objective; and 4, 2-4 foci/X10 objective. $\mathrm{P}=1.00$.

activation, upregulation of p53, p21 and p27, and downregulation of cyclin D1, cyclin E, Cdk2 and Cdk4 protein expression. However, the mechanisms of cell cycle arrest induced by forbesione are only partially understood, and additional experiments are required to provide conclusive answers.

Apoptosis is a highly regulated process that involves the activation of a series of molecular events that lead to a form of cell death (48). Apoptosis is one of the mechanisms occurring in response to cancer therapies (49). Our previous study
Table VII. Histopathological features of stomach tissues (forestomach and glandular stomach) and grading criteria level in each experimental group.

\begin{tabular}{|c|c|c|c|}
\hline \multirow[b]{2}{*}{ Histopathology } & \multirow[b]{2}{*}{ Score } & \multicolumn{2}{|c|}{ Experimental groups } \\
\hline & & $\begin{array}{c}\text { Control, } \\
\mathrm{n}=6 \\
\mathrm{n}(\%)\end{array}$ & $\begin{array}{c}\text { Forbesione } \\
50 \mathrm{mg} / \mathrm{kg}, \\
\mathrm{n}=6 \\
\mathrm{n}(\%)\end{array}$ \\
\hline \multirow[t]{5}{*}{ Inflammation $^{\mathrm{a}}$} & 0 & $6(100.0)$ & $4(66.7)$ \\
\hline & 1 & $0(0.0)$ & $2(33.3)$ \\
\hline & 2 & $0(0.0)$ & $0(0.0)$ \\
\hline & 3 & $0(0.0)$ & $0(0.0)$ \\
\hline & 4 & $0(0.0)$ & $0(0.0)$ \\
\hline
\end{tabular}

a Stomach inflammation score: 0 , none; $1, \leq 1$ focus/X10 objective; 2 , 2-4 foci/X10 objective; 3, 2-4 foci/X10 objective; and 4, 2-4 foci/X10 objective. $\mathrm{P}=0.087$.

demonstrated that forbesione induces apoptosis of human CCA cell lines through the mitochondrial pathway (6). In the present study, it was observed that forbesione treatment of Ham-1 cells caused nuclear morphological changes (chromatin condensation and nuclear fragmentation), increased the proportion of cells in the sub- $\mathrm{G}_{1}$ fraction (representing apoptotic cells) and increased the percentage of apoptotic cells.

DNA fragmentation is the hallmark of apoptosis (50). There are three steps of DNA degradation, identified as a high-molecular weight DNA fragmentation (0.05-1.00 Mb), an intermediate DNA fragmentation $(\sim 300 \mathrm{~Kb})$ and an internucleosomal DNA fragmentation (mono or oligonucleosomal-size fragments) (51). Apoptotic cells, containing internucleosomal-sized fragments, can be identified on DNA content frequency histograms using a flow cytometric assay as cells with fractional ' $\mathrm{sub}-\mathrm{G}_{1}$ ' $\mathrm{DNA}$ content or ' $\mathrm{sub}-\mathrm{G}_{1}$ ' cells, which represent late apoptotic cells $(51,52)$. However, during apoptosis, DNA fragmentation may be terminated at 50-300 $\mathrm{Kb}$ fragments (53), which cannot be identified as 'sub- $\mathrm{G}_{1}$ ' cells (54). Furthermore, apoptotic $\mathrm{G}_{2} / \mathrm{M}$ - or S-phase cells with fractional DNA content may appear at the $G_{1^{-}}$or early S-position on DNA content histograms, but may not be present at the 'sub- $\mathrm{G}_{1}$ ' location (55). Therefore, the sub- $\mathrm{G}_{1}$ DNA content cannot be used to detect all apoptotic cells.

In the early events of apoptosis, externalization of phosphatidylserine to the outer membrane of the cells occurs, which can be detected by annexin V staining (56). PI has been used to differentiate between early apoptotic (annexin $\mathrm{V}^{+}$ and $\mathrm{PI}^{-}$) and late apoptotic or necrotic (annexin $\mathrm{V}^{+}$and $\mathrm{PI}^{+}$) cells, depending on the integrity of the cell membrane, which remains intact during early apoptosis whilst being disrupted during necrosis (56).

The results in Fig. 3 represent both early and late apoptotic cells, which exhibit a higher percentage of apoptotic cells than that of late apoptotic cells in the sub- $G_{1}$ fraction, which is shown in Fig. 2.

The regulation of apoptosis may be divided into three main pathways: i) The extrinsic pathway or death receptor 
Table VIII. Serum ALT, ALP, BUN and creatinine levels in each experimental group.

\begin{tabular}{lccccc}
\hline & \multicolumn{2}{c}{ Kidney function test } & & \multicolumn{2}{c}{ Liver function test } \\
\cline { 2 - 3 } Groups & BUN $(\mathrm{mg} / \mathrm{dl})$ & Creatinine $(\mathrm{mg} / \mathrm{dl})$ & & ALT $(\mathrm{U} / \mathrm{l})$ & ALP $(\mathrm{U} / \mathrm{l})$ \\
\hline Control $(\mathrm{n}=6)$ & $18.80 \pm 1.29$ & $0.31 \pm 0.04$ & & $78.33 \pm 22.87$ & $97.83 \pm 11.03$ \\
Forbesione 50 $\mathrm{mg} / \mathrm{kg}(\mathrm{n}=6)$ & $18.21 \pm 2.33$ & $0.28 \pm 0.04$ & & $66.33 \pm 15.01$ & $102.50 \pm 8.75$ \\
P-value & 0.279 & 0.181 & & 0.157 & 0.105 \\
\hline
\end{tabular}

ALT, alanine transaminase; ALP, alkaline phosphatase; BUN, blood urea nitrogen.

pathway; ii) the intrinsic mitochondrial pathway; and iii) the ER pathway (57). In the extrinsic pathway, binding of Fas ligand to Fas on the cell surface will recruit the adapter protein FADD and procaspase- 8 to form death-inducing signaling complex (DISC) $(58,59)$. In DISC, procaspase- 8 will become activated, forming activated caspase-8, which can directly activate effector caspases-3, -6 and -7 , leading to apoptotic cell death $(58,59)$. Our in vitro study demonstrated that forbesione increased the protein expression of Fas, FADD, procaspase- 8 and activated caspase-3, suggesting apoptosis induction through the extrinsic pathway.

The mitochondrial apoptotic pathway is regulated by the Bcl-2 family of proteins, including the anti-apoptotic members Bcl-2 and Bcl-extra large and the pro-apoptotic members Bax and Bak (60). The equilibrium between the levels of pro-apoptotic and anti-apoptotic proteins is important for cell survival and death (60). An increased ratio of $\mathrm{Bax} / \mathrm{Bcl}-2$ can trigger the release of cytochrome $c$ from mitochondria into the cytoplasm (61). Cytochrome $c$ will form a complex with Apaf-1 and procaspase-9, resulting in the activation of caspase- 9 and caspase-3, leading to apoptotic cell death (61). Survivin, one of the human inhibitors of apoptotic proteins, has been reported to inhibit activated caspase-7 and caspase-3 $(62,63)$. In accord with our previous study $(24)$, the present study demonstrated that the forbesione-mediated induction of apoptosis in Ham-1 cells was associated with decreased levels of Bcl-2 and survivin and with increased levels of Bax, activated caspase- 9 and activated caspase-3, supporting that apoptosis induction is occurring through the mitochondrial pathway. These results agree with the results of our in vivo study, in which forbesione-mediated suppression of tumor growth occurred through reduced expression of Bcl-2 and increased expression of Bax, caspase-9 and caspase-3.

Upon encountering ER stress, the ER pathway is triggered by altered conformation of Bax and Bak in the ER membrane, resulting in $\mathrm{Ca}^{2+}$ efflux that activates the calcium-dependent protease m-calpain in the cytoplasm (36). Subsequently, m-calpain cleaves and activates the ER-resident protein procaspase-12, which subsequently activates procaspase-9 and procaspase-3, thus promoting apoptotic cell death (37). In the present study, forbesione was able to decrease the expression of procaspase-12 while increasing the expression of activated caspase-12, suggesting that the induction of apoptosis was mediated in part through the ER pathway.

$\mathrm{NF}-\kappa \mathrm{B}$ is a transcription factor that controls the expression of several genes involved in the control of cell cycle progression and apoptosis (64). NF- $\kappa$ B consists of a complex of p50 and p65 subunits, and is present in an inactive form when bound to an endogenous inhibitor, $\mathrm{I} \kappa \mathrm{B}$, in the cytoplasm (64). In response to stimuli, I $\kappa \mathrm{B}-\alpha$ kinase (IKK) phosphorylates I $\kappa \mathrm{B}$, leading to its degradation, and consequently $\mathrm{NF}-\kappa \mathrm{B}$ translocates into the nucleus to activate the transcription of its target genes $(40,65)$. Previous studies demonstrated that isomorellin and gambogic acid inhibit $N F-\kappa B$ activation through decreased $N F-\kappa B$ protein expression, and that the inhibition of IKK activation leads to suppressed phosphorylation and degradation of IкB- $\alpha$ as well as to the suppression of the nuclear translocation of $\mathrm{NF}-\kappa \mathrm{B} / \mathrm{p} 65$ (17,21). The role of NF- $\kappa \mathrm{B}$ in cell cycle progression has been previously reported (61). NF- $\kappa \mathrm{B}$ is able to induce the expression of activators of cell cycle progression such as cyclin D3, cyclin E and cyclin A (66). NF- $\kappa$ B also induces the expression of anti-apoptotic genes such as Bcl-2 and survivin (67). Consistent with those studies, the present study identified a decrease in NF- $\kappa \mathrm{B}$ protein expression and an increase in $\mathrm{I} \kappa \mathrm{B}-\alpha$ protein expression, which could possibly cause the inactivation of $\mathrm{NF}-\kappa \mathrm{B}$, resulting in a decrease in protein expression of cyclin $\mathrm{E}$ and cyclin $\mathrm{A}$, thus leading to cell cycle arrest in $\mathrm{S}$ phase and to a decrease in protein expression of $\mathrm{Bcl}-2$ and survivin, thus resulting in apoptosis.

Our in vivo study revealed that forbesione treatment significantly inhibited the growth of Ham-1 allografts. The forbesione-treated hamsters were healthy (with normal physical activities and eating habits) and gained weight. Examination of tissue sections demonstrated no obvious histopathological changes in the vital organs (liver, kidney and stomach) of the hamsters treated daily with $50 \mathrm{mg} / \mathrm{kg}$ (orally). The liver and kidney functions were normal. Our results confirm those of a previous study in which gambogic acid at doses of 30 and $60 \mathrm{mg} / \mathrm{kg}$ (intragastrically) exhibited potent antitumor effects without obvious side effects or toxicity in preclinical experiments (8). However, gambogic acid at a dose of $120 \mathrm{mg} / \mathrm{kg}$ in a long-term follow-up study on rats exhibited toxic effects in the liver and kidney (8).

In conclusion, our study demonstrates for the first time that forbesione inhibits the growth of Ham-1 CCA cells in vitro and suppresses allograft tumor growth in vivo. We propose that forbesione acts via multiple mechanisms, including induction of S-phase cell cycle arrest and multiple pathways of apoptosis (including the death receptor pathway, the mitochondrial pathway and the ER pathway), by altering the expression of genes and proteins that are related to cell cycle and apoptosis regulation. There were no observed side effects or toxicity in hamsters treated with forbesione for 
4 weeks, suggesting that forbesione may represent a promising therapeutic drug for the treatment of cancer. Additional studies leading to clinical trials are merited.

\section{Acknowledgements}

The present study was supported in part by grants from the Center of Excellence for Innovation in Chemistry, Commission on Higher Education (Bangkok, Thailand; grant no. 48-03-3-00-144), Khon Kaen University Research Fund (Khon Kaen, Thailand; grant no. 573301582701) and Khon Kaen University under the Incubation Researcher Project, Khon Kaen University (Khon Kaen, Thailand; grant no. 563902).

\section{References}

1. Sripa B and Pairojkul C: Cholangiocarcinoma: Lessons from Thailand. Curr Opin Gastroenterol 24: 349-356, 2008.

2. Welzel TM, McGlynn KA, Hsing AW, O'Brien TR and Pfeiffer RM: Impact of classification of hilar cholangiocarcinomas (Klatskin tumors) on the incidence of intra-and extrahepatic cholangiocarcinoma in the United States. J Natl Cancer Inst 98: 873-875, 2006.

3. West J, Wood H, Logan R, Quinn M and Aithal G: Trends in the incidence of primary liver and biliary tract cancers in England and Wales 1971-2001. Br J Cancer 94: 1751-1758, 2006.

4. Patt YZ, Hassan MM, Aguayo A, Nooka AK, Lozano RD, Curley SA, Vauthey JN, Ellis LM, Schnirer II, Wolff RA, et al: Oral capecitabine for the treatment of hepatocellular carcinoma, cholangiocarcinoma, and gallbladder carcinoma. Cancer 101: 578-586, 2004.

5. Thongprasert S: The role of chemotherapy in cholangiocarcinoma. Ann Oncol 16: ii93-ii96, 2005.

6. Hahnvajanawong C, Boonyanugomol W, Nasomyon T, Loilome W, Namwat N, Anantachoke N, Tassaneeyakul W, Sripa B, Namwat W and Reutrakul V: Apoptotic activity of caged xanthones from Garcinia hanburyi in cholangiocarcinoma cell lines. World J Gastroenterol 16: 2235-2243, 2010.

7. Saralamp P, Chuakul W, Temsiririrkkul R and Clayton T (eds): Medicinal Plants in Thailand. Vol. 1. Amarin Printing and Publishing Public Co., Ltd., Bangkok, 1996.

8. Wu ZQ, Guo QL, You QD, Zhao L and Gu HY: Gambogic acid inhibits proliferation of human lung carcinoma SPC-A1 cells in vivo and in vitro and represses telomerase activity and telomerase reverse transcriptase mRNA expression in the cells. Bio Pharm Bull 27: 1769-1774, 2004.

9. Han QB, Wang YL, Yang L, Tso TF, Qiao CF, Song JZ, Xu LJ, Chen SL, Yang DJ and Xu HX: Cytotoxic polyprenylated xanthones from the resin of Garcinia hanburyi. Chem Pharm Bull 54: 265-267, 2006.

10. Reutrakul V, Anantachoke N, Pohmakotr M, Jaipetch T, Sophasan S, Yoosook C, Kasisit J, Napaswat C, Santisuk T and Tuchinda P: Cytotoxic and anti-HIV-1 caged xanthones from the resin and fruits of garcinia hanburyi. Planta Med 73: 33-40, 2007.

11. Guo QL, You QD, Wu ZQ, Yuan ST and Zhao L: General gambogic acids inhibited growth of human hepatoma SMMC-7721 cells in vitro and in nude mice. Acta Pharmacol Sin 25: 769-774, 2004

12. Liu W, Guo QL, You QD, Zhao L, Gu HY and Yuan ST: Anticancer effect and apoptosis induction of gambogic acid in human gastric cancer line BGC-823. World J Gastroenterol 11: 3655-3659, 2005.

13. Zhao L, Guo QL, You QD, Wu ZQ and Gu HY: Gambogic acid induces apoptosis and regulates expressions of Bax and Bcl-2 protein in human gastric carcinoma MGC-803 cells. Bio Pharm Bull 27: 998-1003, 2004.

14. Qin Y, Meng L, Hu C, Duan W, Zuo Z, Lin L, Zhang X and Ding J: Gambogic acid inhibits the catalytic activity of human topoisomerase IIalpha by binding to its ATPase domain. Mol Cancer Ther 6: 2429-2440, 2007.

15. Yu J, Guo QL, You QD, Lin SS, Li Z, Gu HY, Zhang HW, Tan Z and Wang X: Repression of telomerase reverse transcriptase mRNA and hTERT promoter by gambogic acid in human gastric carcinoma cells. Cancer Chemother Pharmacol 58: 434-443, 2006.
16. Yu J, Guo QL, You QD, Zhao L, Gu HY, Yang Y, Zhang HW, Tan $Z$ and Wang X: Gambogic acid-induced G2/M phase cell-cycle arrest via disturbing CDK7-mediated phosphorylation of CDC2/p34 in human gastric carcinoma BGC-823 cells. Carcinogenesis 28: 632-638, 2006.

17. Pandey MK, Sung B, Ahn KS, Kunnumakkara AB, Chaturvedi MM and Aggarwal BB: Gambogic acid, a novel ligand for transferrin receptor, potentiates TNF-induced apoptosis through modulation of the nuclear factor-KappaB signaling pathway. Blood 110: 3517-3525, 2007.

18. Guo Q, Qi Q, You Q, Gu H, Zhao L and Wu Z: Toxicological studies of gambogic acid and its potential targets in experimental animals. Basic Clin Pharmacol Toxicol 99: 178-184, 2006.

19. Qi Q, You Q, Gu H, Zhao L, Liu W, Lu N and Guo Q: Studies on the toxicity of gambogic acid in rats. J Ethnopharmacol 117: 433-438, 2008.

20. Qi Q, Gu H, Yang Y, Lu N, Zhao J, Liu W, Ling H, You QD, Wang $X$ and Guo Q: Involvement of matrix metalloproteinase 2 and 9 in gambogic acid induced suppression of MDA-MB-435 human breast carcinoma cell lung metastasis. J Mol Med (Berl) 86: 1367-1377, 2008.

21. Hahnvajanawong C, Ketnimit S, Pattanapanyasat K, Anantachoke N, Sripa B, Pinmai K, Seubwai W and Reutrakul V: Involvement of p53 and nuclear factor-kappaB signaling pathway for the induction of G1-phase cell cycle arrest of cholangiocarcinoma cell lines by isomorellin. Bio Pharm Bull 35: 1914-1925, 2012.

22. Hahnvajanawong C, Wattanawongdon W, Chomvarin C, Anantachoke N, Kanthawong S, Sripa B and Reutrakul V: Synergistic effects of isomorellin and forbesione with doxorubicin on apoptosis induction in human cholangiocarcinoma cell lines. Cancer Cell Int 14: 68, 2014.

23. Puthdee N, Vaeteewoottacharn K, Seubwai W, Wonkchalee O, Kaewkong W, Juasook A, Pinlaor S, Pairojkul C, Wongkham C, Okada S, et al: Establishment of an allo-transplantable hamster cholangiocarcinoma cell line and its application for in vivo screening of anti-cancer drugs. Korean J Parasitol 51: 711-717, 2013.

24. Pinmai K, Chunlaratthanabhorn S, Ngamkitidechakul C, Soonthornchareon N and Hahnvajanawong C: Synergistic growth inhibitory effects of Phyllanthus emblica and Terminalia bellerica extracts with conventional cytotoxic agents: Doxorubicin and cisplatin against human hepatocellular carcinoma and lung cancer cells. World J Gastroenterol 14: 1491-1497, 2008.

25. Bradford MM: A rapid and sensitive method for the quantitation of microgram quantities of protein utilizing the principle of protein-dye binding. Anal Biochem 72: 248-254, 1976.

26. Boonmars T, Srisawangwong T, Srirach P, Kaewsamut B, Pinlaor S and Sithithaworn P: Apoptosis-related gene expressions in hamsters re-infected with Opisthorchis viverrini and re-treated with praziquantel. Parasitol Res 102: 57-62, 2007.

27. Boonmars T, Wu Z, Nagano I and Takahashi Y: Expression of apoptosis-related factors in muscles infected with Trichinella spiralis. Parasitology 128: 323-332, 2004.

28. Lee SO, Nadiminty N, Wu XX, Lou W, Dong Y, Ip C, Onate SA and Gao AC: Selenium disrupts estrogen signaling by altering estrogen receptor expression and ligand binding in human breast cancer cells. Cancer Res 65: 3487-3492, 2005.

29. Wu Z, Boonmars T, Nagano I, Boonjaraspinyo S, Pinlaor S, Pairojkul C, Chamgramol Y and Takahashi Y: Alteration of galectin-1 during tumorigenesis of Opisthorchis viverrini infection-induced cholangiocarcinoma and its correlation with clinicopathology. Tumour Biol 33: 1169-1178, 2012.

30. Wonkchalee O, Boonmars T, Aromdee C, Laummaunwai P, Khunkitti W, Vaeteewoottacharn K, Sriraj P, Aukkanimart R, Loilome W, Chamgramol Y, et al: Anti-inflammatory, antioxidant and hepatoprotective effects of Thunbergia laurifolia Linn. on experimental opisthorchiasis. Parasitol Res 111: 353-359, 2012.

31. Baskić D, Popović S, Ristić P and Arsenijević NN: Analysis of cycloheximide-induced apoptosis in human leukocytes: Fluorescence microscopy using annexin $\mathrm{V} /$ propidium iodide versus acridin orange/ethidium bromide. Cell Biol Int 30: 924-932, 2006.

32. Hengartner MO: The biochemistry of apoptosis. Nature 407: $770-776,2000$

33. Grimm S and Brdiczka D: The permeability transition pore in cell death. Apoptosis 12: 841-855, 2007.

34. Cryns V and Yuan J: Proteases to die for. Genes Dev 12: 1551-1570, 1998.

35. Burlacu A: Regulation of apoptosis by Bcl-2 family proteins. J Cell Mol Med 7: 249-257, 2003. 
36. Szegezdi E, Logue SE, Gorman AM and Samali A: Mediators of endoplasmic reticulum stress-induced apoptosis. EMBO Rep 7: $880-885,2006$

37. Wu J and Kaufman R: From acute ER stress to physiological roles of the unfolded protein response. Cell Death Differ 13: 374-384, 2006.

38. Guttridge DC, Albanese C, Reuther JY, Pestell RG and Baldwin AS Jr: NF-kappaB controls cell growth and differentiation through transcriptional regulation of cyclin D1. Mol Cell Biol 19: 5785-5799, 1999

39. Perkins ND: The Rel/NF-kappa B family: Friend and foe. Trends Biochem Sci 25: 434-440, 2000.

40. Sriraj P, Aukkanimart R, Boonmars T Juasook A, Sudsarn P, Wonkchalee N, Pairojkul C, Waraasawapati S, Laummaunwai $\mathrm{P}$ and Boonjaraspinyo $\mathrm{S}$ : Does a combination of opisthorchiasis and ethyl alcohol consumption enhance early cholangiofibrosis, the risk of cholangiocarcinoma? Parasitol Res 112: 2971-2981, 2013.

41. Zhao W, Zhou SF, Zhang ZP, Xu GP, Li XB and Yan JL: Gambogic acid inhibits the growth of osteosarcoma cells in vitro by inducing apoptosis and cell cycle arrest. Oncol Rep 25: 1289-1295, 2011.

42. Chen J, Gu HY, Lu N, Yang Y, Liu W, Qi Q, Rong JJ, Wang XT, You QD and Guo QL: Microtubule depolymerization and phosphorylation of c-Jun N-terminal kinase-1 and p38 were involved in gambogic acid induced cell cycle arrest and apoptosis in human breast carcinoma MCF-7 cells. Life Sci 83: 103-109, 2008.

43. Graña X and Reddy EP: Cell cycle control in mammalian cells: Role of cyclins, cyclin dependent kinases (CDKs), growth suppressor genes and cyclin-dependent kinase inhibitors (CKIs). Oncogene 11: 211-219, 1995.

44. King K and Cidlowski J: Cell cycle regulation and apoptosis 1. Annu Rev Physiol 60: 601-617, 1998.

45. Yadav V, Sultana S, Yadav J and Saini N: Gatifloxacin induces $\mathrm{S}$ and G2-phase cell cycle arrest in pancreatic cancer cells via p21/p27/p53. PLoS One 7: e47796, 2012.

46. Maga $G$ and Hubscher U: Proliferating cell nuclear antigen (PCNA): A dancer with many partners. J Cell Sci 116: 3051-3060, 2003.

47. Engel FB, Hauck L, Boehm M, Nabel EG, Dietz R and von Harsdorf R: P21(CIP1) controls proliferating cell nuclear antigen level in adult cardiomyocytes. Mol Cell Bio 23. 555-565, 2003.

48. Steller H: Mechanisms and genes of cellular suicide. Science 267: 1445-1449, 1995.

49. Danial NN and Korsmeyer SJ: Cell death: Critical control points. Cell 116: 205-219, 2004.

50. Nagata S: Apoptotic DNA fragmentation. Exp Cell Res 256: $12-18,2000$

51. Kajstura M, Halicka HD, Pryjma J and Darzynkiewicz Z: Discontinuous fragmentation of nuclear DNA during apoptosis revealed by discrete 'sub-G1' peaks on DNA content histograms. Cytometry A 71: 125-131, 2007.

52. Franz S, Frey B, Sheriff A, Gaipl US, Beer A, Voll RE, Kalden JR and Herrmann M: Lectins detect changes of the glycosylation status of plasma membrane constituents during late apoptosis. Cytometry A 69: 230-239, 2006.
53. Oberhammer F, Wilson J, Dive C, Morris ID, Hickman JA, Wakeling AE, Walker PR and Sikorska M: Apoptotic death in epithelial cells: Cleavage of DNA to 300 and/or $50 \mathrm{~kb}$ fragments prior to or in the absence of internucleosomal fragmentation. EMBO J 12: 3679-3984, 1993.

54. Darzynkiewicz Z, Juan G, Li X, Gorczyca W, Murakami T and Traganos F: Cytometry in cell necrobiology: Analysis of apoptosis and accidental cell death (necrosis). Cytometry 27: $1-20,1997$

55. Huang X, Halicka HD, Traganos F, Tanaka T, Kurose A and Darzynkiewicz Z: Cytometric assessment of DNA damage in relation to cell cycle phase and apoptosis. Cell Prolif 38: 223-243, 2005

56. Jakubikova J, Bao Y and Sedlak J: Isothiocyanates induce cell cycle arrest, apoptosis and mitochondrial potential depolarization in HL-60 and multidrug-resistant cell lines. Anticancer Res 25: 3375-3386, 2005.

57. Du Y, Wang K, Fang H, Li J, Xiao D, Zheng P, Chen Y, Fan H, Pan X, Zhao C, Zhang Q, et al: Coordination of intrinsic, extrinsic, and endoplasmic reticulum-mediated apoptosis by imatinib mesylate combined with arsenic trioxide in chronic myeloid leukemia. Blood 107: 1582-1590, 2006.

58. Choi $\mathrm{C}$ and Benveniste EN: Fas ligand/Fas system in the brain: Regulator of immune and apoptotic responses. Brain Res Rev 44: 65-81, 2004.

59. Chatfield $\mathrm{K}$ and Eastman A: Inhibitors of protein phosphatases 1 and 2A differentially prevent intrinsic and extrinsic apoptosis pathways. Biochem Biophys Res Commun 323: 1313-1320, 2004.

60. Liang X, Wu A, Xu Y, Xu K, Liu J and Qian X: B1, a novel naphthalimide-based DNA intercalator, induces cell cycle arrest and apoptosis in HeLa cells via p53 activation. Invest New Drugs 29: 646-658, 2011.

61. Fulda S and Debatin K: Extrinsic versus intrinsic apoptosis pathways in anticancer chemotherapy. Oncogene 25: 4798-4811, 2006.

62. Deveraux QL and Reed JC: IAP family proteins-suppressors of apoptosis. Genes Dev 13: 239-252, 1999.

63. Shin S, Sung BJ, Cho YS, Kim HJ, Ha NC, Hwang JI, Chung $\mathrm{CW}$, Jung YK and Oh BH: An anti-apoptotic protein human survivin is a direct inhibitor of caspase-3 and-7. Biochemistry 40: 1117-1123, 2001.

64. Baldwin AS Jr: The NF-kappaB and I kappaB proteins: New discoveries and insights. Annu Rev Immunol 14: 649-683, 1996.

65. Ghosh S and Karin M: Missing pieces in the NF-kappaB puzzle. Cell 109 (Suppl): S81-S96, 2002.

66. Hsia CY, Cheng S, Owyang AM, Dowdy SF and Liou HC: C-Rel regulation of the cell cycle in primary mouse $\mathrm{B}$ lymphocytes. Int Immunol 14: 905-916, 2002.

67. Tracey L, Perez-Rosado A, Artiga MJ, Pérez-Rosado A, Artiga MJ, Camacho FI, Rodríguez A, Martínez N, Ruiz-Ballesteros E, Mollejo M, et al: Expression of the NF-kappaB targets BCL2 and BIRC5/Survivin characterizes small B-cell and aggressive B-cell lymphomas, respectively. J Pathol 206: 123-134, 2005. 